\title{
Biogeographical analysis of the Chukchi Sea and adjacent waters based on fauna of some macrobenthos taxa
}

\author{
V.V. Petryashov, S.V. Vassilenko, A.Yu. Voronkov, \\ B.I. Sirenko, A.V. Smirnov, I.S. Smirnov
}

Zoological Institute RAS, Universitetskaya nab., 1, St. Petersburg, 199034, Russia. e-mail: malacostraca@zin.ru

A biogeographical analysis was made on the distribution data of 347 species from the Crustacea (Malacostraca); Mollusca (Polyplacophora, Gastropoda and Bivalvia) and Echinodermata (Holothuroidea, Echinoidea, Asteroidea and Ophiuroidea in the northern Bering Sea, Chukchi Sea and eastern East Siberian Sea at 0-150 m depth. The hydrological regime, primarily the distribution of waters of different origins, defined the distribution of macrobenthos species of 19 different biogeographical groups. Boreal and subtropicalboreal species mostly inhabited the southern part of the Chukchi Sea. 38.3-42.3\% of the species occurred from the Central Banks to the Herald canyon and off Alaska from Cape Hope to Point Barrow. In these regions the share of Arctic and Atlantic boreal-Arctic species was only $1.7-4.6 \%$. In the remaining regions the share of boreal and subtropicalboreal species diminished to $23.1-19.1 \%$, but the share of Arctic and Atlantic boreal-Arctic species increased to $10.9-18.0 \%$ (20.3\% for the latter species in adjacent Arctic waters). For these taxa, the boundary between the Pacific and Arctic faunas in the Chukchi Sea passes from the Asian Cape Serdse Kamen northward to the Herald Canyon and then eastward to Point Barrow.

KEY WORDS: biogeography, the Chukchi Sea, macrobenthos.

\section{Биогеографический анализ Чукотского моря и сопредельных вод по фауне некоторых таксонов макробентоса}

\author{
В.В. Петряшёв, С.В. Василенко, А.Ю. Воронков, \\ Б.И. Сиренко, А.В. Смирнов, И.С. Смирнов
}

Зоологический институт РАН, Университетская наб., 1, Санкт-Петербург, 199034, Росcuя. e-mail: malacostraca@zin.ru

Для биогеографического анализа использованы данные о распространении 347 видов Crustacea: Malacostraca; Mollusca: Polyplacophora, Gastropoda, Bivalvia; Echinodermata: Holothuroidea, Echinoidea, Asteroidea, Ophiuroidea, населяющих северную часть Берингова моря, Чукотское море и восточные районы ВосточноСибирского моря на глубинах 0-150 м. Эти виды по типам ареалов объединяются в 19 биогеографических групп. Гидрологический режим, и, в первую очередь, распро- 
странение вод разного генезиса в исследуемых акваториях, определяет пространственное распределение различных биогеографических групп макробентоса. Южная часть Чукотского моря населена преимущественно бореальными и субтропическо-бореальными видами. В районе центральных банок до каньона Геральд и в прибрежных водах у Аляски от мыса Хоп до мыса Барроу доля этих видов в фауне также значительная (38,3-42,3\%), а доля арктических и атлантических бореальноарктических видов очень маленькая (1,7-4,6\%). В остальных районах моря доля бореальных и субтропическо-бореальных видов уменьшается до 23,4-19,1\%, а арктических и атлантических бореально-арктических видов увеличивается до 10,9$18,0 \%$ (в сопредельных арктических водах доля последних видов составляет 20,3\%). Установлено, что граница между тихоокеанской и арктической фаунами проходит от мыса Сердце Камень на азиатском побережье Чукотского моря на север к каньону Геральд и далее на восток к мысу Барроу на американском побережье моря.

КЛЮЧЕВЫЕ СЛОВА: биогеография, Чукотское море, макробентос.

\section{Introduction}

The Chukchi Sea is the only region of the Arctic having a direct water exchange with the North Pacific, also this is an area of contact between the Arctic and Pacific biotas. For this reason the Chukchi Sea region has been of particular interest for marine biogeographers for 150 years. Biogeographical analyses based on different taxonomical groups have yielded differing results, primarily with respect to the boundary between North Pacific (or Pacific boreal) and Arctic (or Arctic subregion of the Arctic-Atlantic region) biogeographical regions.

The geographical names usually mentioned in biogeographical regionalization of the Chukchi and northern Bering seas are shown on Fig. 1. Most authors (Woodword, 1856; Fisher, 1887; Dall, 1909; Andriashev, 1939; Briggs, 1995; and many other subsequent authors) drew the Pacific-Arctic boundary in northern areas of the Bering Sea, south of the Bering Strait, either in the area of Nunivak Island - Gulf of Anadyr, or in the area of St. Lawrence Island (Fig. 2). Golikov (1980) initially drew the boundary from the southern Gulf of Anadyr to Cape Prince of Wales. Other authors considered the Bering Strait area (Kussakin, 1979) or the southern Chukchi Sea (Tzvetkova, 1975) as the boundary between biogeographical regions. Some malacologists (Filatova, 1957; Scarlato, 1981) be- lieved that this boundary passes from Cape Prince of Wales or Cape Dezhnev to Point Barrow: that is they considered the North Pacific region as including areas adjacent to Alaskan coast of the entire Bering and Chukchi seas. Finally, other authors (Makarov, 1941; Kafanov, 1991; Petryashov, 2002a, b) assigned most part of the Chukchi Sea to the North Pacific region. In this case, the boundary passed from Point Barrow to west of Herald Bank (toward Herald Canyon) and then to the coast of the Chukchi Peninsula near Vankarem (Makarov, 1941) or near Cape Serdtse Kamen (Petryashov, 2002a, b) (A.I. Kafanov did not specify the precise areas near the Chukchi Peninsula coast). Ushakov (1952) and Scarlato and Golikov (1985) were more cautious in considering the northern Bering Sea and some southern areas of the Chukchi Sea as a transitional zone between the Arctic and Pacific boreal faunas.

These significant differences in the results of previous biogeographical analyses were probably caused by a number of factors. These included: insufficient data, use of different methods for revealing biogeographical borders, climatic fluctuations in the region over time, and the specificity of the taxon (usually an order or a class) used for biogeographical analysis. Different groups of fauna have varying capacities for active dispersal and differences in ontogeny and thermopathy. Therefore, ideally, the bioge- 


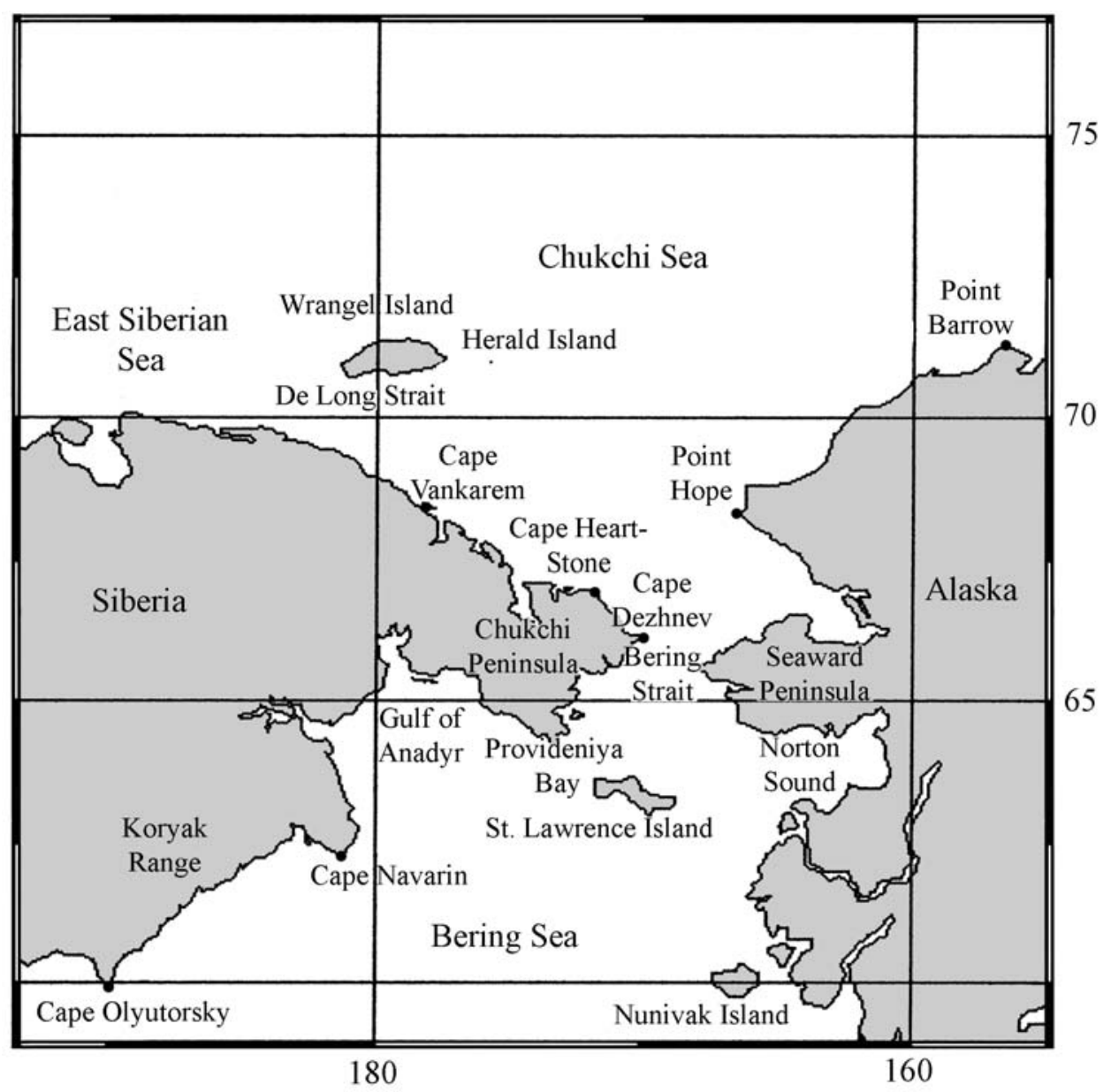

Fig. 1. Study area.

Рис. 1. Район исследования.

ographical pattern should be determined based on the distribution of all macrobenthos species (Kussakin, 1967). Regretfully, this suggestion still remains just a good intention. The problems are the laboriousness of the analyses and the lack of extensive knowledge on all taxonomic groups in the region. Nevertheless, the present study attempted to approach this ideal. To analyze biogeographically the Chukchi Sea and adjacent waters, we used distribution data on the taxa that are most numerous at $0-150 \mathrm{~m}$ depth in the region: Mollusca (Polyplacophora, Gastropoda and Bivalvia) Echinodermata and Crustacea (mainly Malacostraca).

\section{Material and methods}

The distributions of a total of 347 macrobenthic species occurring in the northern Bering Sea, north of $60^{\circ} \mathrm{N}$, the Chukchi Sea and the eastern East Siberian Sea, east of $170^{\circ} \mathrm{E}$ were considered. Of these, 285 species occured in the Chukchi Sea: Polyplacophora -8 species (5 species recorded in the Chukchi Sea), Gastropoda - 123 species (102 species recorded in the Chukchi Sea), Bivalvia - 93 species ( 75 species recorded in the Chukchi Sea), Malacostraca 86 species (72 species recorded in the Chukchi Sea), and Echinodermata -38 species (30 


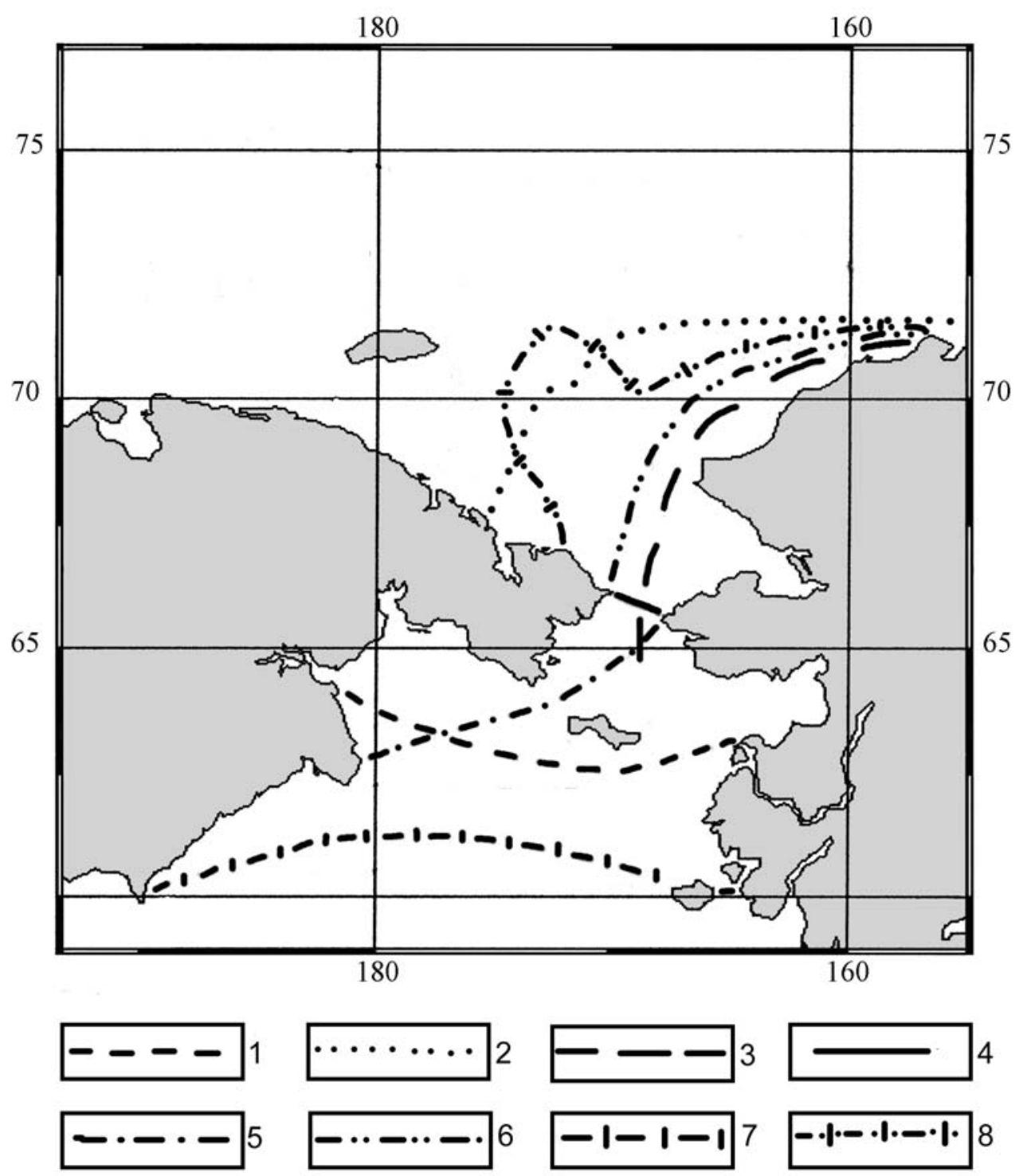

Fig. 2. Boundary between Arctic (or Arctic-Atlantic) and Northern Pacific biogeographic regions according to different publications.

1 - after Andriashev, 1939; 2 - after Makarov, 1941; 3 - after Filatova, 1957; 4 - after Kussakin, 1979; 5 - after Golikov, 1980; 6 - after Scarlato, 1981; 7 - after Briggs, 1995; 8 - after Petryashov, 2002b.

Рис. 2. Границы между Арктической (или Арктатлантической) и Северотихоокеанской биогеографическими областями по разным авторам.

1 - по А.П.Андрияшеву (1939); 2 - по В.В.Макарову (1941); 3 - по З.А.Филатовой (1957); 4 - по О.Г.Кусакину (1979); 5 - по А.Н.Голикову (1980); 6 - по О.А.Скарлато (1981); 7 — по Дж.К.Бриггсу (1995); 8 - по В.В. Петряшёву (20002b).

species recorded in the Chukchi Sea). The majority of the data was obtained, by the authors, from collections made between 19762000 . Additional data was taken from the inven- tory of collections stored in the Zoological Institute of the RAS and as from the literature (Rathbun, 1910; Makarov, 1938, 1941; Banner, 1948a, b; Djakonov, 1950, 1952, 1954; Tatter- 
sall, 1951; Ushakov, 1952; Gurjanova, 1952; Gorbunov, 1952; Holmquist, 1973, 1975, 1980, 1981a, b, 1982; McLaughlin, 1974; Feder, Jewett, 1978; Kussakin, 1979, 1982, 1988, 1999, 2003; Golikov, 1980, 1994; Scarlato, 1981; Foster, 1981; Golikov et al., 1994; Vassilenko, 1994; Naumov, Fedyakov, 1994; Bogdanov, 1994; Smirnov, Smirnov, 1994, 2009; Petryashov, 2002a, b, 2005; Sirenko, 2010a, b).

For biogeographical analysis, the region was divided into areas concurring with the borders of some species natural habitats. Besides, the borders of some areas coincide with the boundaries of biogeographical regions and subregions suggested in published schemes (Andriyashev, 1939; Kussakin, 1979; Scarlato, 1981; Briggs, 1995; Petryashov, 2002b). In total, 12 such areas were recognized (Fig. 3): Koryak (D1) the shelf of the Koryak Upland coast between Cape Olyutorsky and Cape Navarin; Nunivak (D2) - the shelf of Alaskan coast from Nunivak Island to Yukon River Delta; Anadyr (D3) Gulf of Anadyr; Norton(D4) - Norton Bay and southern shore of St. Lawrence Island; Chirikov (D5) - Chirikov basin: from St. Lawrence Island to Bering Strait; South Chukchi (D6) southern Chukchi Sea from Bering Strait to Cape Serdtse Kamen and Cape Hope; Central Chukchi (D7) - the area of central banks of the Chukchi Sea to Herald Canyon in the zone of influence of Herald branch of the Pacific Current; Alaskan (D8) — off northwestern Alaska in the zone of Alaskan branch of the Pacific Current between Cape Hope and Barrow Point; Chukchi (D9) — offChukchi Peninsula coast in the zone of occurrence of cold water from the East Siberian Sea, from Cape Serdtse Kamen to De Long Strait; West Chukchi(D10) — western Chukchi Sea southward of $72^{\circ} 30^{\prime} \mathrm{N}$, westward of Herald Canyon, including De Long Strait; North Chukchi (D11) - outer shelf of the Chukchi Sea; East Siberian (D12) — eastern East Siberian Sea eastward of $170^{\circ} \mathrm{E}$.

The present biogeographical analysis included the study of distribution of the total macrobenthic species diversity, biogeographical structure of fauna, and the estimation of similarity between faunas by means of the sim- ilarity/diversity indices: Jaccard $\left(\mathrm{I}_{\mathrm{J}}\right)$, Czekanowski-Sørensen $\left(\mathrm{I}_{\mathrm{CS}}\right)$ and Szymkiewicz-Simpson $\left(\mathrm{I}_{\mathrm{SzS}}\right)$ (Pesenko, 1982).

The boundaries between the biogeographical regions often coincide with borders of species ranges. Usually, the more species range borders coinciding in a narrow zone, the more significant is the biogeographical boundary marked by this zone. Changes of fauna in the zone of border between areas $\mathrm{D}_{\mathrm{x}}-\mathrm{D}_{\mathrm{y}}$ can be expressed as $n_{x} / n_{y}$, where $n_{x}$ is the number of species occurring in the area $D_{x}$ but not penetrating into the area $\mathrm{D}_{\mathrm{y}}$ further than the border zone; $\mathrm{n}_{\mathrm{y}}$ is the number of species occurring in the area $D_{y}^{y}$ but not penetrating into the area $D_{x}$ further than the border zone. To reveal the degree of the range borders concentration on the boundary zone, with an account for the faunal species richness, Petryashov and Pesenko (Petryashov, 2009) suggested the coefficient of range borders concentration $(d)$ :

$\mathrm{d}=\mathrm{a} / \mathrm{b}(\%)$, where $\mathrm{a}=\mathrm{n}_{\mathrm{x}}+\mathrm{n}_{\mathrm{y}}, \mathrm{a} \mathrm{b}=\left(\mathrm{N}_{\mathrm{x}}+\right.$ $\left.\mathrm{N}_{\mathrm{y}}-\mathrm{a}\right) / 2+\mathrm{a}$; or (simplified)

$\mathrm{d}=2\left(\mathrm{n}_{\mathrm{x}}+\mathrm{n}_{\mathrm{y}}\right) /\left(\mathrm{N}_{\mathrm{x}}+\mathrm{N}_{\mathrm{y}}+\mathrm{n}_{\mathrm{x}}+\mathrm{n}_{\mathrm{y}}\right)(\%)$

where $\mathrm{N}_{\mathrm{x}}$ is the number of species inhabiting an area $\mathrm{D}_{\mathrm{x}} ; \mathrm{N}_{\mathrm{y}}$ is the number of species inhabiting an area $\mathrm{D}_{\mathrm{y}}$. Consequently, the faunas are more similar at low values of the coefficient.

\section{Results and discussion}

\section{Regularities in the distribution of mac-} robenthic species diversity in the Chukchi Sea and adjacent regions

The faunas of the Chukchi Sea and adjacent regions of the Bering and East Siberian seas are still insufficiently studied. The data are especially poor for invertebrates in the area of the Central Banks of the Chukchi Sea (area D7) and its outer shelf(area D11). Nevertheless, considering the entire dataset used (Table 1), there is a trend of decreasing the number of macrobenthic species from the North Bering Sea to the furthermost Arctic areas. The North Bering Sea (areas D1-D5, $60^{\circ} \mathrm{N}$ to the Bering Strait) and the South Chukchi Sea (area D6) harbour 165- 


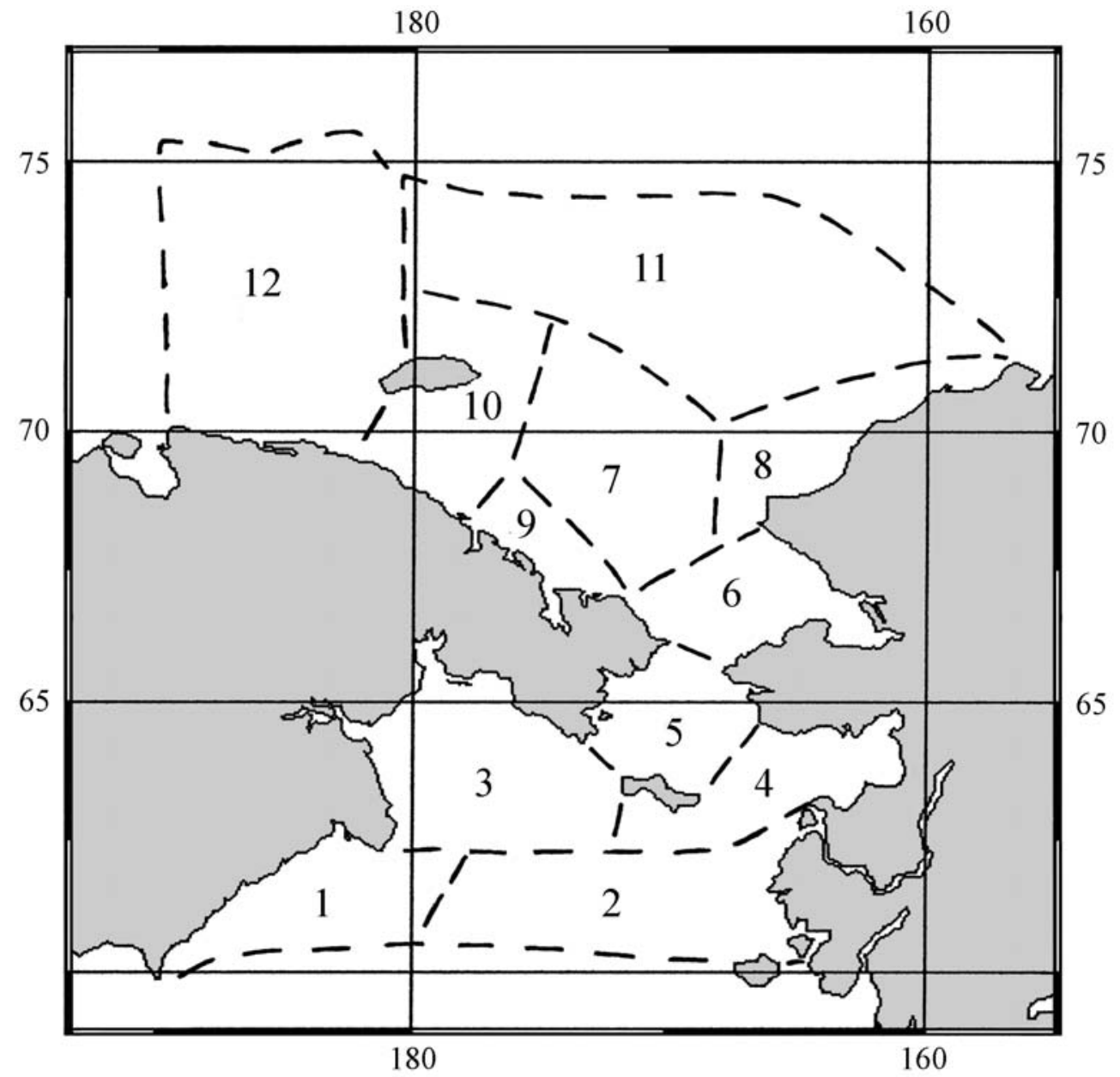

Fig. 3. Areas used in the biogeographical analysis.

Рис. 3. Районы, выделенные для проведения биогеографического анализа.

261 macrobenthic species. Remarkably, their number is almost the same along western coast of the Bering Sea (areas D1 and D3), in the Chirikov basin (D5) and in South Chukchi Sea (D6), 246-261 species, whereas a lower number, 165-195 species is recorded from off the Bering Sea coast America (areas D2 and D4). A similar pattern of a decrease in the number of species in eastern Bering Sea, compared to the western part of the Sea, is recorded for the Polyplacophora, Gastropoda, Echinodermata, and most orders of Malacostraca. In contrast, the Bivalvia and Decapoda show no or very small differences in the species numbers along the American and Asian coasts of the Bering Sea. A decrease in the total species number in Nunivak (D2) and Norton (D4) areas is probably explained by insufficient knowledge on several macrobenthic taxa from these areas, or by peculiarities of the sediment properties.

North and northwest of the line Cape Serdtse Kamen - Cape Hope (areas D7-D10), the number of macrobenthic species in each area is 50-70\% lower compared with the number in the South Chukchi area (D6): 110-175 species. In areas where the Pacific Current branches (D7D8), the species number is relatively higher (115-175 species) than in areas influenced by 
Table 1. Distribution of the number of macrobenthos species in the Chukchi Sea and adjacent areas. Таблица 1. Распределение количества видов макробентоса в Чукотском море и сопредельных акваториях.

\begin{tabular}{|l|c|c|c|c|c|c|c|c|c|c|c|c|}
\hline Taxa & D1 & D2 & D3 & D4 & D5 & D6 & D7 & D8 & D9 & D10 & D11 & D12 \\
\hline Malacostraca & 58 & 23 & 53 & 31 & 54 & 55 & 20 & 29 & 26 & 29 & 12 & 19 \\
\hline Loricata & 7 & 0 & 7 & 3 & 5 & 4 & 0 & 2 & 2 & 2 & 0 & 0 \\
\hline Gastropoda & 102 & 70 & 103 & 74 & 98 & 89 & 47 & 73 & 30 & 54 & 21 & 52 \\
\hline Bivalvia & 60 & 59 & 64 & 67 & 74 & 65 & 30 & 49 & 41 & 41 & 20 & 31 \\
\hline Echinodermata & 31 & 13 & 30 & 20 & 30 & 28 & 18 & 22 & 11 & 19 & 8 & 16 \\
\hline Total macrobenthos & 258 & 165 & 257 & 195 & 261 & 241 & 115 & 175 & 110 & 145 & 61 & 118 \\
\hline
\end{tabular}

Remark. D1-D12 correspond to areas used in the biogeographical analysis (see Fig. 1).

the surface water of the East Siberian Sea and most transformed Pacific water (areas D9-D10), $110-145$ species (although fauna in area D7 is not as well studied). The coldest part of the Chukchi Sea, at its outer shelf (area D11) has 61 species in the taxa considered. It is unlikely that, even after more detailed studies, this number will equal the number for the East Siberian Sea (area D12), 118 species.

A similar distribution of species numbers is shown by most taxa (Table 1). However, the number of species of higher crustaceans and bivalve molluscs only slightly varies between areas D7-D10 and the number of few recorded species of polyplacophoran molluscs gradually decreases from the southwestern Bering Sea (areas D1 and D3, 7 species in each) northward (areas D8-D10, 2 species in each); in some areas (D2, D7, D11, and D12) these species were absent.

Species lists for both the entire macrobenthos studied and for particular classes from neighboring areas usually differ, at least to some extent, as shown by $\left(\mathrm{n}_{\mathrm{x}} / \mathrm{n}_{\mathrm{y}}\right)$ and the range border coefficient (d) (Table 2). The lowest d values for both the entire macrobenthos and the individual classes are recorded in the "Asian" areas, from Koryak (D1) to South Chukchi (D6): D1, D3, D5, and D6. Therefore, their fauna is the most homogeneous, values for the entire macrobenthos are higher between "Asian" and "American" areas, 29.9-43.0\%, and reach a maximum for the Nunivak area (D2). The differences are primarily explained by considerable differentiation of the Malacostraca fauna and, to a lesser extent, the Echinodermata and
Polyplacophora. These faunal differences may decrease with further investigation of the North Bering Sea biota will smooth over. Nevertheless, the more significant differences between faunistic lists for the Chukchi Sea areas are explained by insufficient knowledge of the biota of respective areas and by the gradual transition from the North Pacific to the Arctic fauna. The most significant faunal changes are recorded at the border between the Alaskan (D8) and North Chukchi (D11) areas ( $\mathrm{d}=76.4 \%)$, as well as between North Chukchi (D11) and East Siberian $(\mathrm{D} 12), \mathrm{d}=71.2 \%$. The $\mathrm{d}$ values of 60 $65.4 \%$ are characteristic of the following pairs of areas: South Chukchi (D6) - Chukchi (D9), Central Chukchi (D7) - North Chukchi (D11), and WestChukchi(D10)-North Chukchi(D11). $\mathrm{d}$ values of $52.9-53.5 \%$ are recorded for two pairs of areas: South Chukchi (D6) - Central Chukchi (D7) and Central Chukchi (D7) - Alaskan(D8), while values of $42.4-46.2 \%$ are known for three pairs: Central Chukchi (D7) - West Chukchi (D10), Chukchi (D9) - West Chukchi D10), and West Chukchi (D10) - East Siberian (D12). Considering the South Chukchi (D6) Alaskan (D8) transition d was $35.6 \%$ for the entire macrobenthos, but 52.6, 50.0, and 42.4\% for the Malacostraca, Loricata, and Bivalvia, respectively.

\section{Biogeographical structure of the fauna}

Before proceeding to the analysis of the biogeographical structure, two terms should be clarified: Arctic and boreal species. Sublittoral 
Table 2. Values of the index of species not passing from one area to another $\left(\mathrm{n}_{\mathrm{x}} / \mathrm{n}_{\mathrm{y}}\right)$ and the coefficient of the range borders concentration for adjacent areas $(\mathrm{d} \%)$.

Таблица 2. Значения показателя числа видов, не проникающих из одного района в другой $\left(\mathrm{n}_{\mathrm{x}} / \mathrm{n}_{\mathrm{y}}\right)$ и коэффициента сгущения границ ареалов для сопредельных районов (d\%).

\begin{tabular}{|c|c|c|c|c|c|c|c|}
\hline & & Malacostraca & Loricata & Gastropoda & Bivalvia & Echinodermata & $\begin{array}{l}\text { Total } \\
\text { macrobenthos }\end{array}$ \\
\hline \multirow{2}{*}{ D1-D2 } & $\mathrm{n}_{1} / \mathrm{n}_{2}$ & $40 / 5$ & - & $31 / 1$ & $12 / 10$ & $17 / 0$ & $100 / 16$ \\
\hline & $\mathrm{d}_{1-2}$ & 71.4 & - & 31.4 & 28.4 & 55.7 & 43.0 \\
\hline \multirow{2}{*}{ D1-D3 } & $\mathrm{n}_{2} / \mathrm{n}_{3}$ & $9 / 4$ & - & $1 / 3$ & $4 / 8$ & $1 / 0$ & $15 / 15$ \\
\hline & $\mathrm{d}_{2-3}$ & 21.0 & - & 3.8 & 17.6 & 3.2 & 11.0 \\
\hline \multirow{2}{*}{ D2-D3 } & $\mathrm{n}_{2} / \mathrm{n}_{3}$ & $6 / 36$ & - & $1 / 33$ & $8 / 14$ & $0 / 16$ & $15 / 99$ \\
\hline & $\mathrm{d}_{2-3}$ & 71.2 & - & 32.9 & 30.3 & 54.2 & 42.5 \\
\hline \multirow{2}{*}{ D2-D4 } & $\mathrm{n}_{2} / \mathrm{n}_{4}$ & $2 / 11$ & - & $0 / 3$ & $0 / 8$ & $0 / 7$ & $2 / 29$ \\
\hline & $\mathrm{d}_{2-4}$ & 38.8 & - & 4.1 & 11.9 & 35.0 & 15.9 \\
\hline \multirow{2}{*}{ D3-D4 } & $\mathrm{n}_{3} / \mathrm{n}_{4}$ & $29 / 8$ & $4 / 0$ & $30 / 1$ & $10 / 12$ & $9 / 0$ & $82 / 21$ \\
\hline & $d_{3-4}$ & 61.2 & 57.1 & 29.8 & 28.8 & 30.5 & 37.1 \\
\hline \multirow{2}{*}{ D3-D5 } & $\mathrm{n}_{3} / \mathrm{n}_{5}$ & $5 / 6$ & $2 / 0$ & $6 / 1$ & $6 / 14$ & $1 / 1$ & $20 / 22$ \\
\hline & $\mathrm{d}_{3-5}$ & 18.6 & 28.6 & 6.7 & 25.3 & 6.5 & 15.0 \\
\hline \multirow{2}{*}{ D4-D5 } & $\mathrm{n}_{4} / \mathrm{n}_{5}$ & $4 / 26$ & $0 / 2$ & $3 / 27$ & $1 / 8$ & $0 / 9$ & $8 / 72$ \\
\hline & $\mathrm{d}_{4-5}$ & 52.2 & 40.0 & 29.7 & 12.0 & 30.5 & 29.9 \\
\hline \multirow{2}{*}{ D5-D6 } & $\mathrm{n}_{5} / \mathrm{n}_{6}$ & $4 / 6$ & $1 / 0$ & $12 / 3$ & $9 / 0$ & $2 / 0$ & $28 / 9$ \\
\hline & $\mathrm{d}_{5-6}$ & 16.8 & 20.0 & 14.9 & 12.2 & 6.7 & 13.7 \\
\hline \multirow{2}{*}{ D6-D7 } & $\mathrm{n}_{6} / \mathrm{n}_{7}$ & $36 / 1$ & - & $42 / 0$ & $36 / 1$ & $11 / 1$ & $125 / 3$ \\
\hline & $d_{6-7}$ & 66.1 & - & 47.2 & 56.1 & 41.4 & 52.9 \\
\hline \multirow{2}{*}{ D6-D8 } & $\mathrm{n}_{6} / \mathrm{n}_{8}$ & $28 / 2$ & $2 / 0$ & $20 / 5$ & $22 / 6$ & $5 / 0$ & $77 / 13$ \\
\hline & $\mathrm{d}_{6-8}$ & 52.6 & 50.0 & 26.7 & 42.4 & 18.2 & 35.6 \\
\hline \multirow{2}{*}{ D6-D9 } & $\mathrm{n}_{6} / \mathrm{n}_{9}$ & $35 / 6$ & $3 / 1$ & $59 / 0$ & $28 / 4$ & $18 / 2$ & $143 / 13$ \\
\hline & $\mathrm{d}_{6-9}$ & 67.2 & 80.0 & 66.3 & 46.2 & 67.8 & 61.5 \\
\hline \multirow{2}{*}{ D7-D8 } & $\mathrm{n}_{7} / \mathrm{n}_{8}$ & $7 / 15$ & - & $10 / 36$ & $5 / 24$ & $2 / 7$ & $24 / 82$ \\
\hline & $\mathrm{d}_{7-8}$ & 62.0 & - & 55.4 & 53.7 & 36.7 & 53.5 \\
\hline \multirow{2}{*}{ D7-D9 } & $\mathrm{n}_{7} / \mathrm{n}_{9}$ & $12 / 17$ & - & $25 / 8$ & $6 / 17$ & $9 / 3$ & $52 / 45$ \\
\hline & $\mathrm{d}_{7-9}$ & 77.3 & - & 60.0 & 48.9 & 58.6 & 60.2 \\
\hline \multirow{2}{*}{ D7-D1 0} & $\mathrm{n}_{7} / \mathrm{n}_{10}$ & $9 / 17$ & - & $6 / 13$ & $4 / 15$ & $2 / 4$ & $21 / 49$ \\
\hline & $\mathrm{d}_{7-10}$ & 69.2 & - & 31.7 & 42.2 & 27.9 & 42.4 \\
\hline \multirow{2}{*}{ D7-D1 1} & $\mathrm{n}_{7} / \mathrm{n}_{11}$ & $16 / 7$ & - & $29 / 3$ & $15 / 5$ & $10 / 1$ & $70 / 16$ \\
\hline & $\mathrm{d}_{7-11}$ & 83.6 & - & 64.0 & 57.1 & 59.5 & 65.6 \\
\hline \multirow{2}{*}{ D8-D1 1} & $\mathrm{n}_{8} / \mathrm{n}_{11}$ & $22 / 5$ & - & $56 / 4$ & $35 / 6$ & $16 / 2$ & $129 / 17$ \\
\hline & $\mathrm{d}_{8-11}$ & 79.4 & - & 77.9 & 63.1 & 75.0 & 76.4 \\
\hline \multirow{2}{*}{ D9-D10 } & $\mathrm{n}_{0} / \mathrm{n}_{10}$ & $6 / 9$ & $1 / 1$ & $3 / 27$ & $8 / 6$ & $2 / 10$ & $20 / 53$ \\
\hline & $\mathrm{d}_{0-10}$ & 42.9 & 66.7 & 52.6 & 29.2 & 57.1 & 44.5 \\
\hline \multirow{2}{*}{ D10-D11 } & $\mathrm{n}_{10} / \mathrm{n}_{11}$ & $20 / 3$ & - & $37 / 4$ & $23 / 2$ & $11 / 0$ & $91 / 9$ \\
\hline & $\mathrm{d}_{10-11}$ & 71.9 & - & 70.7 & 58.1 & 57.9 & 65.4 \\
\hline \multirow{2}{*}{ D $10-D 12$} & $\mathrm{n}_{10} / \mathrm{n}_{12}$ & $13 / 3$ & - & $17 / 15$ & $15 / 5$ & $7 / 4$ & $52 / 27$ \\
\hline & $\mathrm{d}_{10-12}$ & 50.0 & - & 46.4 & 44.0 & 40.7 & 46.2 \\
\hline \multirow{2}{*}{ D11-D 12} & $\mathrm{n}_{11} / \mathrm{n}_{12}$ & $6 / 13$ & - & $7 / 38$ & $7 / 18$ & $0 / 10$ & $20 / 79$ \\
\hline & $\mathrm{d}_{10-12}$ & 76.0 & - & 76.3 & 65.8 & 58.8 & 71.2 \\
\hline
\end{tabular}

Remark. D1-D12 are areas used in the biogeographical analysis (see Fig. 1); $\mathrm{n}_{\mathrm{x}}$ is the number of species not passisng from Dx to Dy area, $n_{y}$ ia the number of species not passing from Dy to Dx area; $d_{x-y}$ is the value of the coefficient of the range border concentration for the area pair Dx-Dy.

Arctic species inhabit the Arctic subregion (or province) and transitory zones between artic and boreal biogeograpical regions. Sublittoral boreal species occur in boreal biogeographical regions of the Pacific and Atlantic as well as in transitory zones.
The types of ranges for species occurring in the Arctic have been described previously ( $\mathrm{Si}$ renko et al., 2008). The suggested classification can be supplemented by addition of another three types of ranges: Arctic-boreal, amphiboreal-Arctic (Petryashov, 2002b) and widespread 
in the World Ocean. The macrobenthic species occurring in the Chukchi Sea and adjacent areas of the Bering and East Siberian seas can be assigned to 19 biogeographical groups according to their distribution.

1. Arctic (Arct.) - 10 species in the studied region $(2.9 \%), 7$ species in the Chukchi Sea $(2.5 \%)$.

2. Arctic-boreal (A-b) - 7 species in the studied region $(2.0 \%), 6$ species in the Chukchi Sea $(2.1 \%)$; they occur circumpolarly in the Arctic and also occur in cold temperate waters northward of the lines Labrador Peninsula Finnmark in the Atlantic sector and Care Navarin (southeastern Chukchi Peninsula) - Cape Prince of Wales (Alaska: Bering Strait) in the Pacific sector. They may occur in some bays (fjords) of the Koryak Upland coast.

3. Atlantic widespread boreal-Arctic (Atl. w-b-a) -6 species in the studied region $(1.7 \%)$, 5 species in the Chukchi Sea (1.8\%).

4. Atlantic high-boreal-Arctic (Atl.h-b-a.) 11 species in the studied region $(3.2 \%), 9$ species in the Chukchi Sea (3.2\%).

5. Widespread boreal-Arctic (Wba) -80 species in the studied region $(23.1 \%), 76$ species in the Chukchi Sea (26.7\%).

6. High-boreal-Arctic $(\mathrm{Hba})-19$ species in the studied region $(5.5 \%), 17$ species in the Chukchi Sea (6.0\%).

7. Pacific widespread boreal-Arctic (Pac. wb-a) - 14 species in the studied region $(4.0 \%)$, 14 species in the Chukchi Sea (4.9\%).

8. Pacific high-boreal-Arctic (Pac. h-b-a) 15 species in the studied region $(4.3 \%), 15$ species in the Chukchi Sea (5.3\%).

9. Pacific - West Atlantic boreal-Arctic (Pac. wa-b-a) -4 species in the studied region $(1.2 \%), 4$ species in the Chukchi Sea (1.4\%).

10. Amphiboreal-Arctic (Amph. b-a) - 12 species in the studied region (3.5\%), 10 species in the Chukchi Sea (3.5\%); their distribution is similar to that typical of wide-spread borealArctic and high-boreal-Arctic species but their ranges in the Arctic show a gap either in the Laptev and East Siberian seas or in the East Siberian and Chukchi seas. These species enter Arctic waters only in the Atlantic sector of the
Arctic and they are distributed in the Pacific and in the Chukchi Sea like Pacific boreal species.

11. Amphiboreal (Amph. b) - 15 species in the studied region $(4.3 \%), 14$ species in the Chukchi Sea (4.9\%).

12. Pacific widespread boreal (Pac. w-b) 54 species in the studied region $(15.6 \%), 43$ species in the Chukchi Sea (15.1\%).

13. Pacific high-boreal (Pac. hb) - 33 species in the studied region $(9.5 \%), 23$ species in the Chukchi Sea $(8.1 \%)$.

14. West Pacific widespread boreal (WP$\mathrm{wb})-38$ species in the studied region $(11.0 \%)$, 24 species in the Chukchi Sea (8.4\%).

15. West Pacific high-boreal (WP-hb) - 14 species in the studied region $(4.0 \%), 6$ species in the Chukchi Sea $(2.1 \%)$.

16. East Pacific widespread boreal (EPwb) -1 species in the studied region $(0.3 \%), 1$ species in the Chukchi Sea (0.4\%).

17. East Pacific high-boreal (EP- hb) -2 species in the studied region $(0.6 \%), 2$ species in the Chukchi Sea $(0.7 \%)$.

18. Pacific subtropical-boreal (Pac. s-b) 11 species in the studied region $(3.2 \%), 8$ species in the Chukchi Sea (2.8\%).

19. Widespread in the World Ocean (Ws) 1 species in the studied region $(0.3 \%), 1$ species in the Chukchi Sea (0.4\%). This species, Ctenodiscus crispatus, occurs in Arctic and temperate waters of the Northern Hemisphere, at Pacific shores of America, and also in deep waters of tropical areas.

The widespread boreal-Arctic, Pacific widespread boreal, West Pacific widespread boreal, and Pacific high-boreal species are the most species-rich in the Chukchi Sea and adjacent areas. Usually species of the same biogeographical groups prevail in the fauna of separate benthic macrotaxa. The relationship between species numbers in different biogeographical groups slightly changes from taxon to taxon (Fig. 4).

The very small proportion of Arctic species is a characteristic of macrobenthic fauna of the region. There is also a rather small share of Atlantic boreal-Arctic, and Arctic-boreal species which, excluding southern populations of Arctic-boreal species, are mainly indicators of 


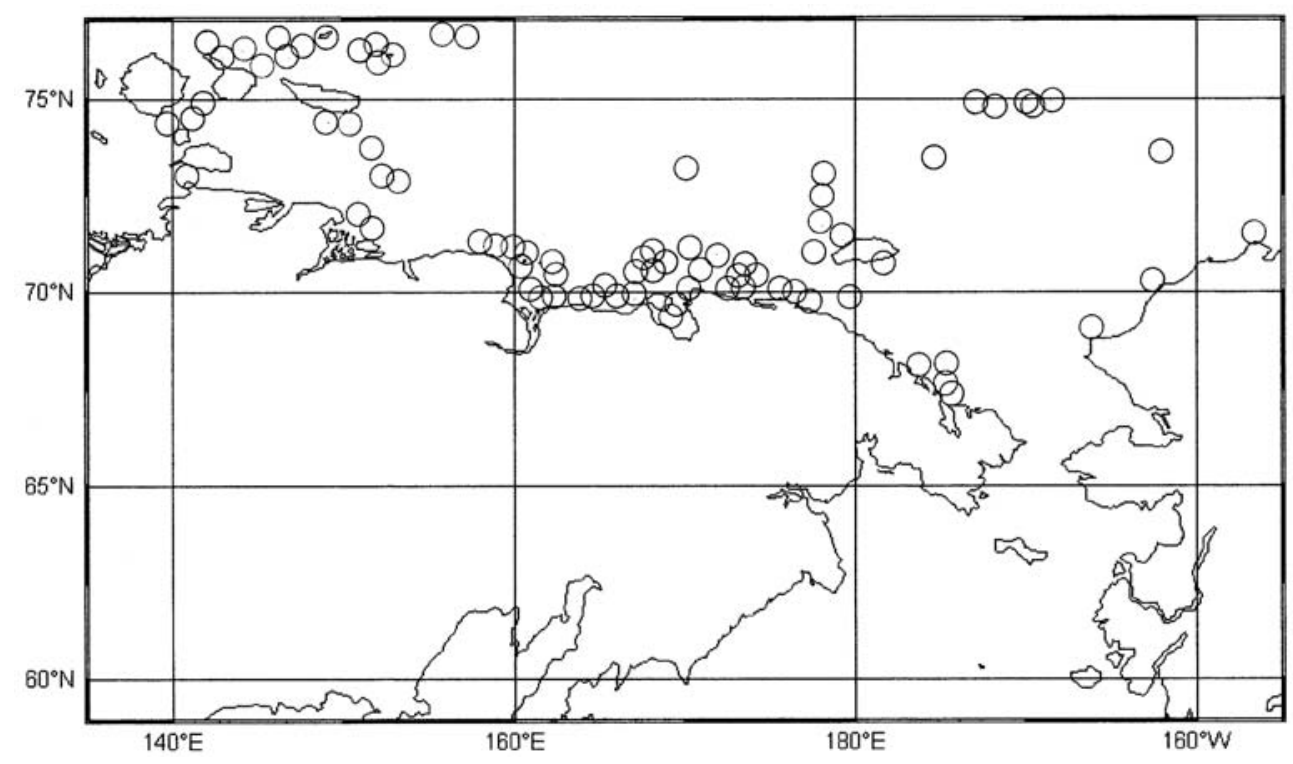

Fig. 4. Stations where Arctic Malacostraca species were sampled in the Chukchi, Bering, and East Siberian seas. After Petryashov, 2002b, fig. 3.

Рис. 4. Станции, на которых в Чукотском, Беринговом и Восточно-Сибирском морях были пойманы арктические виды Malacostraca (по: Петряшев, 2002b, рис. 3).

Arctic-derived water. All of them can be united as a "cold-water" group of species: 34 species in the region $(9.8 \%)$ and 27 species in the Chukchi Sea (9.5\%) (Fig. 4, Table 3 and 4).

In contrast, the share of boreal and of amphiboreal-Arctic macrobenthic species is much greater in the region. They, together with a few Pacific subtropical-boreal species, form a "warm-water" group of species that mainly inhabit waters of Pacific origin: 180 species in the entire region $-51.9 \%, 131$ in the Chukchi Sea $46.0 \%$ (Fig. 5). Other boreal-Arctic species are also numerous: 132 species in the entire region $38.0 \%, 126$ in the Chukchi Sea - 44.2\% (Fig. 6). Typical Arctic areas, like the shelf of the Laptev Sea, harbour about $70 \%$ of the borealArctic species (and, therewith, in non-freshened areas the share of Atlantic boreal-Arctic species is $21-43 \%$, while that of other boreal-Arctic is 28-64\%). Other species are Arctic, and their share in the macrobenthic fauna is $29 \%$ on average (13.5-32.5 in slightly freshened areas).
Boreal and subtropical-boreal species are absent in the Laptev Sea (Petryashov et al., 2004). High-boreal areas of the North Pacific lack Arctic and Atlantic boreal-Arctic species, whereas the share of boreal species is no less than 45$50 \%$ (Petryashov, 2005). The macrobenthic fauna of the region studied is of a transitory character (Pacific boreal to Arctic) but is more similar to the Pacific boreal.

The fauna of Polyplacophora has no "coldwater" species. Similarly, in other groups, the share of "cold-water" species is also low, from $6.5 \%$ in Bivalvia to $14.0 \%$ in Malacostraca.

Proper Arctic species are present only in the higher crustaceans (6 species) and gastropod molluscs (4 species), The share of boreal species in the Chukchi Sea, and therefore all "warmwater" species, is similar to that for the highboreal North Pacific fauna for higher crustaceans $(47.2 \%)$, polyplacophoran and bivalvian molluscs and echinoderms ( $40 \%$ in each group) and lower for gastropods (34.0\%). 
Table 3. Distribution of the macrobenthos species number by complexes of biogeographical groups. Таблица 3. Распределение количества видов макробентоса по комплексам биогеографических

групп.

\begin{tabular}{|c|c|c|c|c|c|c|c|c|c|c|c|c|}
\hline \multirow{2}{*}{ Виды } & \multicolumn{2}{|c|}{ Total macrobenthos } & \multicolumn{2}{|c|}{ Malacostraca } & \multicolumn{2}{|c|}{ Bivalvia } & \multicolumn{2}{|c|}{ Loricata } & \multicolumn{2}{|c|}{ Gastropoda } & \multicolumn{2}{|c|}{ Echinodermata } \\
\hline & $\mathrm{R}$ & $\mathrm{CS}$. & $\mathrm{R}$ & CS. & $\mathrm{R}$ & CS. & $\mathrm{R}$ & $\mathrm{CS}$ & $\mathrm{R}$ & $\mathrm{CS}$ & $\mathrm{R}$ & $\overline{C S}$ \\
\hline "Cold-wa ter" & 34 & 27 & 12 & 10 & 6 & 4 & - & - & 12 & 10 & 4 & 3 \\
\hline Boreal-Arctic & 132 & 126 & 21 & 21 & 38 & 34 & 3 & 3 & 54 & 54 & 17 & 14 \\
\hline "Warm-water" & 180 & 131 & 53 & 41 & 49 & 37 & 5 & 2 & 57 & 39 & 16 & 12 \\
\hline Widespread & 1 & 1 & $\overline{-}$ & - & - & - & - & - & - & - & 1 & 1 \\
\hline Total number of species & 347 & 285 & 86 & 72 & 93 & 75 & 8 & 5 & 123 & 102 & 38 & 30 \\
\hline
\end{tabular}

Remark. R — within the entire studied region; CS — in the Chukchi Sea. Species: "Cold-water" are species of the "cold-water" complex of Arctic, Arctic-boreal, and all Atlantic boreal-Arctic; Boreal-Arctic are all boreal-Arctic without amphiboreal-Arctic and Atlantic boreal-Arctic; "Warm-water" are all boreal, subtropical-boreal and amphiborealArctic; Widespread are those widely spread in the World Ocean.

Relations between faunas of the areas based on similarity indices

An analysis of the entire macrobenthos between two adjacent areas using similarity indices (Table 5) shows that the areas D1-D6, as well as D6-D8, D7-D10, D9-D10, and D10D12 are characterized by values of the Jaccard $\left(\mathrm{I}_{\mathrm{J}}\right)$ and Czekanowski-Sørensen $\left(\mathrm{I}_{\mathrm{ChS}}\right)$ indices greater than $50 \%$, whereas the SzymkewiczSimpson index $\left(\mathrm{I}_{\text {ShS }}\right)$ values exceed $75 \%$. The values of Jaccard index slightly lower than $50 \%$ at high values of the other indices are characteristic of the areas D6-D7 and D7-D8. In other adjacent areas the similarity of macrobenthic fauna is considerably less, especially for the area D11 as compared to other adjacent areas, and the areas D7-D9.

A similar analysis of the fauna of different macrotaxa shows much in common with the results for the entire macrobenthos, although each taxon has some peculiarities. In the fauna of Malacostraca, high values of similarity indices are observed for the group of areas D1, D3, D5-D6 at a certain difference of near-American areas. The areas D7 and D8 are more faunistically similar both to each other and to D6 area than to the areas D9 and D10. The two latter areas, as well as the area D12, are characterized by high values of similarity indices. The lowest values of the indices were found for D11 with other adjacent areas. That is, the faunal changes from south to north occur in higher crustaceans more sharply than on average for the macrobenthos, but even in this case there is a small intermediate zone (areas D9 and D10) between Pacific boreal and Arctic areas. The faunal pattern for Bivalvia is contrary to that in Malacostraca: there are very gradual changes in the fauna of adjacent areas together with high values of similarity indices. Similar results were also obtained for Polyplacophora: high values of the indices are characteristic for all areas, except for the areas D9 and D10 where impoverished faunas differ both from each other and from the fauna of the area D6. The results of the analysis for Gastropoda and Echinodermata are virtually identical with general pattern for the entire macrobenthos. The only difference is that echinoderm faunas of the areas D11 and D12 have much more common characters than faunas of other studied taxa.

\section{Division of the studied region based} on the entire macrobenthic fauna

The biogeographical analysis of all the studied taxa shows, with a possible exception of the Malacostraca, that the southern areas, D1-D6, represent a single minimally recognizable biogeographical unit. This biogeographical unit (district) is a part of the Chukchi-Bering province of the Far Eastern subregion of the North Pacific region (Fig. 7). Only the distribution of species of higher crustaceans allows the possible separation of Nunivak (D2) and Norton (D4) areas as a separate biogeographical district.

The Arctic region, or the Arctic subregion of the Arctic-Atlantic region, includes the East Siberian area (D12). It probably also includes 
Table 4. Distribution of the macrobenthos species from different biogeographical groups within the studied region.

Таблица 4. Распределение количества видов макробентоса различных биогеографических групп в пределах исследуемого региона.

\begin{tabular}{|c|c|c|c|c|c|c|c|c|c|c|c|c|c|c|}
\hline & D1 & D2 & D3 & D4 & D5 & D6 & D7 & D8 & D9 & D10 & D11 & D12 & $\mathbf{R}$ & $\mathrm{CS}$ \\
\hline \multicolumn{15}{|l|}{$\begin{array}{l}\text { Total } \\
\text { macrobenthos: }\end{array}$} \\
\hline Arct. & - & - & - & - & - & - & - & 2 & 4 & 5 & 2 & 7 & 10 & 7 \\
\hline Atl. w-b-a & - & - & - & - & - & - & 1 & 2 & 1 & 2 & 4 & 3 & 6 & 5 \\
\hline Atl. h-b-a. & - & - & - & - & - & 2 & - & 2 & 2 & 3 & 3 & 7 & 11 & 9 \\
\hline A-b & 2 & 1 & 4 & 2 & 4 & 4 & 1 & 2 & 5 & 6 & 2 & 7 & 7 & 6 \\
\hline Wba & 61 & 46 & 64 & 57 & 67 & 69 & 43 & 58 & 50 & 59 & 29 & 55 & 80 & 76 \\
\hline $\mathrm{Hba}$ & 13 & 8 & 15 & 13 & 16 & 15 & 7 & 13 & 8 & 10 & 3 & 12 & 19 & 17 \\
\hline Pac. w-b-a & 12 & 8 & 13 & 10 & 13 & 13 & 9 & 9 & 10 & 11 & 3 & 11 & 14 & 14 \\
\hline Pac. h-b-a & 11 & 6 & 12 & 8 & 15 & 14 & 8 & 8 & 8 & 12 & 2 & 12 & 15 & 15 \\
\hline Pac. wa-b-a & 2 & 1 & 2 & 1 & 2 & 3 & 1 & 4 & 1 & 2 & - & - & 4 & 4 \\
\hline Amph. b-a & 11 & 6 & 10 & 7 & 11 & 10 & 5 & 5 & 4 & 3 & 1 & - & 12 & 10 \\
\hline Amph. b & 10 & 7 & 10 & 7 & 12 & 11 & 6 & 6 & 1 & 2 & 2 & - & 15 & 14 \\
\hline Pac. w-b & 50 & 37 & 47 & 40 & 49 & 43 & 15 & 32 & 8 & 9 & 4 & 2 & 54 & 43 \\
\hline Pac. hb & 27 & 15 & 25 & 18 & 24 & 20 & 7 & 15 & 2 & 7 & - & - & 33 & 23 \\
\hline WP- wb & 37 & 12 & 34 & 15 & 30 & 22 & 6 & 9 & 4 & 9 & 3 & 1 & 38 & 24 \\
\hline WP-hb & 13 & 7 & 12 & 6 & 8 & 5 & 2 & 3 & - & 2 & 1 & - & 14 & 6 \\
\hline EP-wb & - & - & - & - & - & 1 & - & - & - & - & - & - & 1 & 1 \\
\hline EP- hb & - & 2 & - & 2 & 1 & 1 & - & - & - & - & - & - & 2 & 2 \\
\hline Pac. s-b & 8 & 8 & 8 & 8 & 8 & 7 & 3 & 4 & 2 & 2 & 1 & - & 11 & 8 \\
\hline Ws & 1 & 1 & 1 & 1 & 1 & 1 & 1 & 1 & - & 1 & 1 & 1 & 1 & 1 \\
\hline Total species & 258 & 165 & 257 & 195 & 261 & 241 & 115 & 175 & 110 & 145 & 61 & 118 & 347 & 285 \\
\hline & & & & & & & & & & & & & & \\
\hline \multicolumn{15}{|l|}{ Malacostraca: } \\
\hline Arct. & - & - & - & - & - & - & - & 1 & 4 & 4 & 2 & 5 & 6 & 5 \\
\hline Atl. w-b-a & - & - & - & - & - & - & - & - & - & - & 2 & - & 2 & 2 \\
\hline Atl. h-b-a & - & - & - & - & - & - & - & - & - & - & - & 1 & 1 & - \\
\hline A-b & 2 & 1 & 1 & 1 & 2 & 2 & - & 1 & 3 & 3 & 1 & 3 & 3 & 3 \\
\hline $\mathrm{Wba}$ & 8 & 5 & 10 & 6 & 10 & 13 & 6 & 6 & 11 & 10 & 2 & 8 & 17 & 17 \\
\hline $\mathrm{Hba}$ & 2 & - & 2 & 2 & 2 & 2 & 1 & 2 & 1 & 1 & 1 & 1 & 2 & 2 \\
\hline Pac. wa-b-a & 1 & - & 1 & - & 1 & 1 & - & 2 & 1 & - & - & - & 2 & 2 \\
\hline Amph. b-a. & 3 & - & 2 & - & 2 & 2 & 1 & 1 & - & - & - & - & 3 & 2 \\
\hline Amph. b & 1 & - & 1 & - & 2 & 1 & 2 & - & - & - & - & - & 3 & 2 \\
\hline Pac. w-b & 16 & 7 & 13 & 10 & 14 & 13 & 5 & 7 & 3 & 3 & 1 & 1 & 16 & 13 \\
\hline Pac. hb & 5 & 1 & 5 & 3 & 5 & 4 & 2 & 1 & - & 1 & - & - & 6 & 3 \\
\hline WP-wb & 15 & 4 & 13 & 6 & 12 & 11 & 1 & 6 & 2 & 5 & 2 & - & 16 & 13 \\
\hline WP-hb & 1 & 1 & 1 & - & $\begin{array}{ll}- \\
-\end{array}$ & - & - & - & - & - & - & - & 2 & 1 \\
\hline EP-wb & - & - & - & - & - & 1 & - & - & - & - & - & - & 1 & 1 \\
\hline EP- hb & - & 1 & - & 1 & - & - & - & - & - & - & - & - & 1 & 1 \\
\hline Pac. s-b & 4 & 3 & 4 & 2 & 4 & 5 & 2 & 2 & 1 & 2 & 1 & - & 5 & 5 \\
\hline Total species & 58 & 23 & 53 & 31 & 54 & 55 & 20 & 29 & 26 & 29 & 12 & 19 & 86 & 72 \\
\hline & & & & & & & & & & & & & & \\
\hline \multicolumn{15}{|l|}{ Bivalvia: } \\
\hline Atl.w-b-a & - & - & - & - & - & - & - & 1 & - & - & 1 & 2 & 2 & 1 \\
\hline Atl.h-b-a & - & - & - & - & - & - & - & - & 1 & 1 & 1 & - & 2 & 2 \\
\hline A-b & - & - & 1 & 1 & 1 & 1 & - & 1 & 2 & 2 & - & 2 & 2 & 1 \\
\hline Wba & 22 & 21 & 23 & 24 & 25 & 24 & 17 & 20 & 21 & 24 & 13 & 21 & 28 & 26 \\
\hline $\mathrm{Hba}$ & 1 & 1 & 2 & 3 & 3 & 2 & - & 1 & 1 & 2 & - & 1 & 3 & 2 \\
\hline Pac. w-b-a & 2 & 3 & 3 & 3 & 3 & 3 & 2 & 2 & 2 & 2 & 2 & 2 & 3 & 3 \\
\hline Pac. h-b-a & - & - & 1 & 1 & 3 & 2 & 1 & 1 & 2 & 3 & - & 3 & 4 & 3 \\
\hline Amph. b-a & 3 & 3 & 3 & 4 & 4 & 4 & 2 & 2 & 3 & 2 & 1 & - & 4 & 4 \\
\hline
\end{tabular}


Table 4 (contituing) Таблица 4 (продолжение)

\begin{tabular}{|c|c|c|c|c|c|c|c|c|c|c|c|c|c|c|}
\hline & D1 & D2 & D3 & D4 & D5 & D6 & D7 & D8 & D9 & D10 & D11 & D12 & $\mathbf{R}$ & CS \\
\hline A-b & - & - & 1 & 1 & 1 & 1 & - & 1 & 2 & 2 & - & 2 & 2 & 1 \\
\hline Wba & 22 & 21 & 23 & 24 & 25 & 24 & 17 & 20 & 21 & 24 & 13 & 21 & 28 & 26 \\
\hline $\mathrm{Hba}$ & 1 & 1 & 2 & 3 & 3 & 2 & - & 1 & 1 & 2 & $\begin{array}{llll}- & & & \end{array}$ & 1 & 3 & 2 \\
\hline Pac. w-b-a & 2 & 3 & 3 & 3 & 3 & 3 & 2 & 2 & 2 & 2 & 2 & 2 & 3 & 3 \\
\hline Pac. h-b-a & - & $\begin{array}{ll}- & \\
\end{array}$ & 1 & 1 & 3 & 2 & 1 & 1 & 2 & 3 & $\begin{array}{llll}- & & & \end{array}$ & 3 & 4 & 3 \\
\hline Amph. b-a & 3 & 3 & 3 & 4 & 4 & 4 & 2 & 2 & 3 & 2 & 1 & - & 4 & 4 \\
\hline Amph. b & 2 & 4 & 2 & 3 & 3 & 3 & - & 1 & - & - & - & - & 4 & 4 \\
\hline Pac. w-b & 18 & 20 & 18 & 20 & 21 & 18 & 5 & 14 & 5 & 3 & 2 & - & 22 & 18 \\
\hline Pac. hb & 4 & 3 & 5 & 3 & 5 & 4 & 2 & 4 & 2 & 2 & - & - & 8 & 6 \\
\hline WP- wb & 4 & - & 3 & - & 2 & 1 & - & - & 1 & - & $\begin{array}{lll}- & & \\
\end{array}$ & - & 4 & 1 \\
\hline WP-hb & 2 & - & 1 & - & - & - & - & - & - & - & - & - & 2 & - \\
\hline EP- hb & - & 1 & $\begin{array}{lll}- & & \end{array}$ & 1 & 1 & 1 & $\begin{array}{lll}- & \\
\end{array}$ & - & $\begin{array}{l}- \\
\end{array}$ & $\begin{array}{llll}- & & & \end{array}$ & $\begin{array}{llll}- & & & \end{array}$ & $\begin{array}{lll}- & & \end{array}$ & 1 & 1 \\
\hline Pac. s-b & 2 & 3 & 2 & 4 & 3 & 2 & 1 & 2 & 1 & - & - & - & 4 & 3 \\
\hline Total species & 60 & 59 & 64 & 67 & 74 & 65 & 30 & 49 & 41 & 41 & 20 & 31 & 93 & 75 \\
\hline & & & & & & & & & & & & & & \\
\hline \multicolumn{15}{|l|}{ Loricata: } \\
\hline Wba & 2 & - & 2 & 2 & 2 & 2 & - & 2 & 2 & 2 & - & - & 3 & 3 \\
\hline Pac. w-b & 2 & - & 2 & - & 1 & 1 & - & - & $\overline{-}$ & $\overline{-}$ & $\overline{-}$ & - & 2 & 1 \\
\hline Pac. hb & 3 & - & 3 & 1 & 2 & 1 & - & - & - & - & $\begin{array}{lll}- & & \end{array}$ & - & 3 & 1 \\
\hline Total species & 7 & - & 7 & 3 & 5 & 4 & - & 2 & 2 & 2 & - & - & 8 & 5 \\
\hline & & & & & & & & & & & & & & \\
\hline \multicolumn{15}{|l|}{ Gastropoda: } \\
\hline Arct. & - & - & - & - & - & - & - & 1 & - & 1 & - & 2 & 4 & 2 \\
\hline Atl. w-b-a & - & - & - & - & - & - & - & 1 & - & 1 & - & 1 & 1 & 1 \\
\hline Atl. h-b-a & - & $\begin{array}{ll}- & \\
\end{array}$ & $\begin{array}{llll}- & & & \end{array}$ & $\begin{array}{lll}- & & \end{array}$ & $\begin{array}{lll}- & & \end{array}$ & 2 & $\begin{array}{lll}- & \\
\end{array}$ & 2 & $\begin{array}{l}- \\
\end{array}$ & 1 & 1 & 3 & 5 & 5 \\
\hline $\mathrm{A}-\mathrm{b}$ & - & - & 2 & - & 1 & 1 & 1 & - & - & 1 & 1 & 2 & 2 & 2 \\
\hline Wba & 24 & 18 & 24 & 21 & 25 & 25 & 16 & 25 & 14 & 18 & 11 & 23 & 26 & 25 \\
\hline $\mathrm{Hba}$ & 8 & 6 & 9 & 6 & 9 & 9 & 5 & 9 & 4 & 5 & 1 & 8 & 10 & 10 \\
\hline Pac. w-b-a & 6 & 4 & 6 & 4 & 6 & 6 & 5 & 5 & 6 & 6 & 1 & 6 & 6 & 6 \\
\hline Pac. h-b-a & 11 & 6 & 11 & 7 & 11 & 11 & 6 & 6 & 5 & 9 & 1 & 8 & 11 & 11 \\
\hline Pac. wa-b-a & - & - & $\begin{array}{lll}- & & \\
-\end{array}$ & - & - & 1 & - & 1 & - & - & - & - & 1 & 1 \\
\hline Amph. b-a & 5 & 3 & 5 & 3 & 5 & 4 & 2 & 2 & 1 & 1 & - & - & 5 & 4 \\
\hline Amph. b & 3 & 2 & 3 & 2 & 3 & 3 & 2 & 2 & - & 1 & 2 & - & 4 & 4 \\
\hline Pac. w-b & 6 & 6 & 6 & 6 & 6 & 4 & 1 & 5 & - & 1 & 1 & - & 7 & 5 \\
\hline Pac. hb & 14 & 10 & 12 & 10 & 11 & 10 & 3 & 9 & - & 4 & - & - & 15 & 12 \\
\hline WP- wb & 14 & 8 & 14 & 8 & 13 & 9 & 4 & 2 & - & 3 & 1 & - & 15 & 10 \\
\hline WP-hb & 9 & 5 & 9 & 5 & 7 & 4 & 2 & 3 & 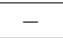 & 2 & 1 & - & 9 & 4 \\
\hline Pac. s-b & 2 & 2 & 2 & 2 & 1 & - & - & - & - & - & - & - & 2 & - \\
\hline Total species & 102 & 70 & 103 & 74 & 98 & 89 & 47 & 73 & 30 & 54 & 21 & 52 & 123 & 102 \\
\hline & & & & & & & & & & & & & & \\
\hline \multicolumn{15}{|l|}{ Echinodermata: } \\
\hline Atl. w-b-a & - & - & - & - & - & - & 1 & - & 1 & 1 & 1 & 1 & 1 & 1 \\
\hline Atl. h-b-a & - & $\begin{array}{lll}- & & \\
\end{array}$ & 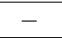 & $\begin{array}{lll}- & & \\
\end{array}$ & $\begin{array}{lll}- & & \\
\end{array}$ & $\begin{array}{lll}- & & \\
\end{array}$ & $\begin{array}{lll}- & & \\
\end{array}$ & $\begin{array}{llll}- & & & \end{array}$ & 1 & 1 & 1 & 3 & 3 & 2 \\
\hline Wba & 5 & 2 & 5 & 4 & 5 & 5 & 4 & 5 & 2 & 5 & 3 & 3 & 6 & 5 \\
\hline $\mathrm{Hba}$ & 2 & 1 & 2 & 2 & 2 & 2 & 1 & 1 & 2 & 2 & 1 & 2 & 4 & 2 \\
\hline Pac. w-b-a & 4 & 1 & 4 & 3 & 4 & 4 & 2 & 2 & 2 & 3 & - & 3 & 5 & 5 \\
\hline Pac. h-b-a. & - & - & - & - & 1 & 1 & 1 & 1 & 1 & 1 & 1 & 1 & 1 & 1 \\
\hline Pac. wa-b-a & 1 & 1 & 1 & 1 & 1 & 1 & 1 & 1 & - & 1 & - & - & 1 & 1 \\
\hline Amph. b & 4 & 1 & 4 & 2 & 4 & 4 & 2 & 3 & 1 & 1 & - & - & 4 & 4 \\
\hline Pac. w-b & 8 & 4 & 7 & 4 & 7 & 7 & 4 & 6 & - & 2 & - & 1 & 7 & 6 \\
\hline Pac. hb & 1 & 1 & 1 & 1 & 1 & 1 & - & 1 & - & - & - & - & 1 & 1 \\
\hline WP- wb & 4 & - & 4 & 1 & 3 & 1 & 1 & 1 & 1 & 1 & 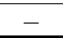 & 1 & 3 & - \\
\hline WP-hb & 1 & 1 & 1 & 1 & 1 & 1 & $\begin{array}{lll}- & & \\
\end{array}$ & $\begin{array}{ll}- & \\
\end{array}$ & $\begin{array}{ll}- \\
\end{array}$ & $\begin{array}{llll}- & & & \\
\end{array}$ & $\begin{array}{llll}- & & & \\
\end{array}$ & - & 1 & 1 \\
\hline
\end{tabular}


Table 4 (contituing)

Таблица 4 (продолжение)

\begin{tabular}{|l|c|c|c|c|c|c|c|c|c|c|c|c|c|c|}
\hline & D1 & D2 & D3 & D4 & D5 & D6 & D7 & D8 & D9 & D10 & D11 & D12 & R & CS \\
\hline Ws & 1 & 1 & 1 & 1 & 1 & 1 & 1 & 1 & - & 1 & 1 & 1 & 1 & 1 \\
\hline Total species & 31 & 13 & 30 & 20 & 30 & 28 & 18 & 22 & 11 & 19 & 8 & 16 & 38 & 30 \\
\hline
\end{tabular}

Remark. D1-D12 are areas recognized for the biogeographical analysis (see Fig. 1). R — the entire studied region, CS - the Chukchi Sea. Biogeographical groups of species are as follows: Arct. - Arctic; Atl. w-b-a - Atlantic widespread boreal-Arctic; Atl. h-b-a - Atlantic high-boreal-Arctic; A-b - Arctic-boreal; Wba -widespead borealArctic; Hba - high-boreal-Arctic; Pac. w-b-a — Pacific widespread boreal-Arctic; Pac. h-b-a - Pacific high-borealArctic; Pac. wa-b-a — Pacific-West-Atlantic-boreal-Arctic; Amph. b-a — amphiboreal-Arctic; Amph. b - amphiboreal; Pac. w-b -Pacific widespread boreal; Pac. hb - Pacific high-boreal; WP-wb - West-Pacific widespread boreal; WP-hb - West-Pacific high-boreal; EP-hb — East-Pacific high-boreal; Pac. s-b - Pacific subtropical-boreal; Ws widespread in the Worls Ocean.

the outer shelf of the Chukchi Sea (D11), which still remains one of the least studied areas in the Arctic. Areas D7-D10 represent a transition zone from one biogeographical region to another. On the American Shelf this zone is probably situated east of Barrow Canyon and includes western part of the Beaufort Sea. A transition from one fauna to another within the Chukchi Sea, primarily in the zone of the Herald Branch of the Bering Sea Current, occurs very gradually in the faunas of echinoderms, gastropods, and, especially, bivalves. At the same time, the transitory zone is very heterogeneous in macrobenthic fauna. Areas D7-D8 are virtually identical with D1-D6 in the fauna of most macrobenthic taxa, that is the fauna of these areas is more similar to the Pacific boreal than to the Arctic. There is a more substantial component of Arctic elements in areas D9-D10. Thus, the border between biogeographical regions mostly coincides with the "Makarov's line"(Makarov, 1941; Kafanov, 1991; Petryashov, 2002b), i.e. Cape Serdtse Kamen - Herald Canyon - Point Barrow. The only exception is the fauna of polyplacophoran mollusks, in which the north boundary of the Pacific boreal fauna of Polyplacophora coincides with the north border of the South Chukchi area (D6). North of this area, the fauna of these molluscs contains a few widespread boreal-Arctic species with the absence of both boreal and Arctic species. Therefore, in respect to polyplacophoran molluscan fauna, it seems justified to consider all other areas of the Chukchi Sea and adjacent Arctic seas as a transitory boreal-Arctic district between the Pacific and Atlantic faunas.

\section{Effect of the hydrological regime of} the studied areas on the macrobenthos distribution

The distribution of biogeographically different macrobenthic species in the Chukchi Sea is closely associated with the hydrological regime of the sea, primarily with respect to the direction of the main currents. Pacific water penetrates into the Chukchi Sea through the Bering Strait and then moves in a single flow to Cape Hope where it divides into two branches (Ratmanov, 1937; Ushakov, 1952; Nikiforov, Schpeicher, 1980). One branch passes along the Alaskan shore to Point Barrow. The other branch passes over the area of the central banks to the north of Wrangel and Herald islands, and at Herald Canyon bifurcates again. Part of the Pacific water spreads along the canyon northward, to the Arctic Basin. As Pacific water passes from the Bering Strait northward, it undergoes a transformation, primarily reflected in a decreasing of temperature. Small flows of cold water occasionally penetrate into the Chukchi Sea from the Arctic Basin and the Beaufort Sea at Point Barrow and from the East Siberian Sea along the north of Wrangel Island. However, these small masses of water of Arctic origin meet the flows of Pacific water and are rapidly transformed. Most of the cold water enters the Chukchi Sea from the East Siberian Sea through the De Long Strait and then passes along the Chukchi Peninsula coast, as far as the Bering Strait in some years, but usually, with a complete transformation, not reaching it. Boreal and 


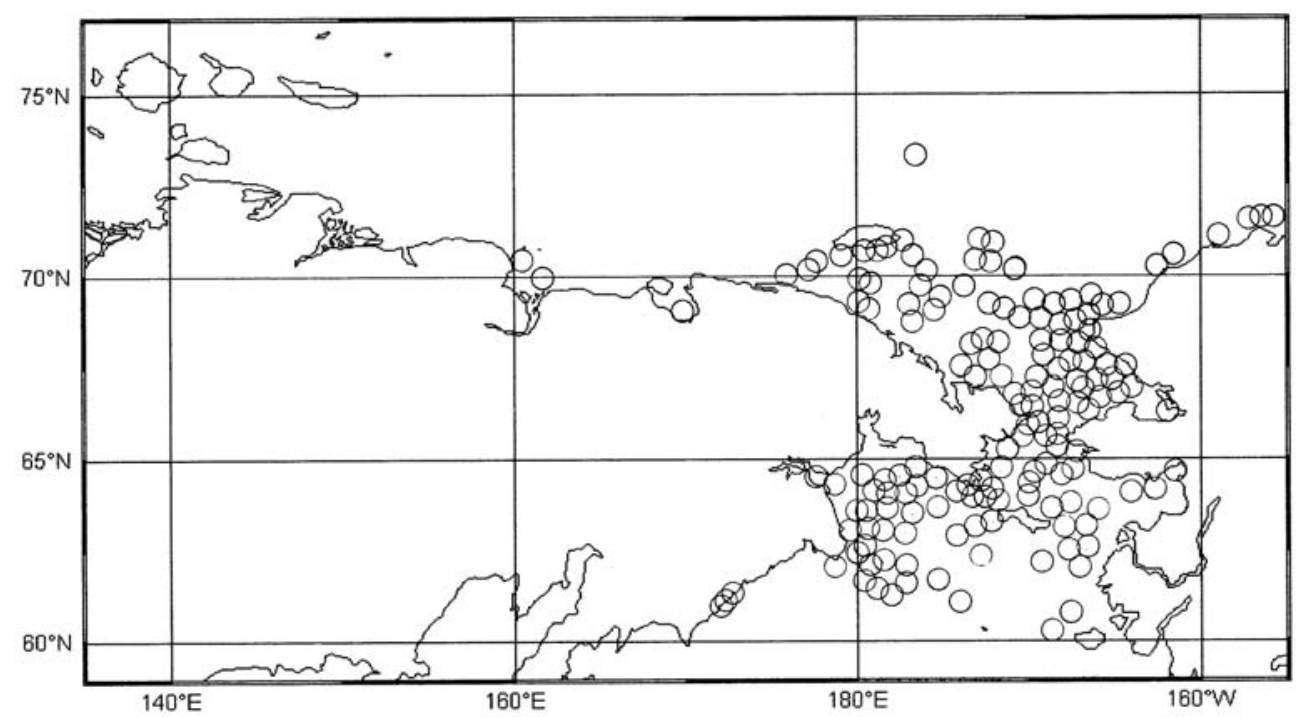

Fig. 5. Stations where Pacific boreal and subtropical Malacostraca species were sampled in the Chukchi, Bering, and East Siberian seas. After Petryashov, 2002b, fig. 2.

Рис. 5. Станции, на которых в Чукотском, Беринговом и Восточно-Сибирском морях были пойманы тихоокеанские бореальные и субтропические виды Malacostraca (по: Петряшев, 2002b, pис. 2).

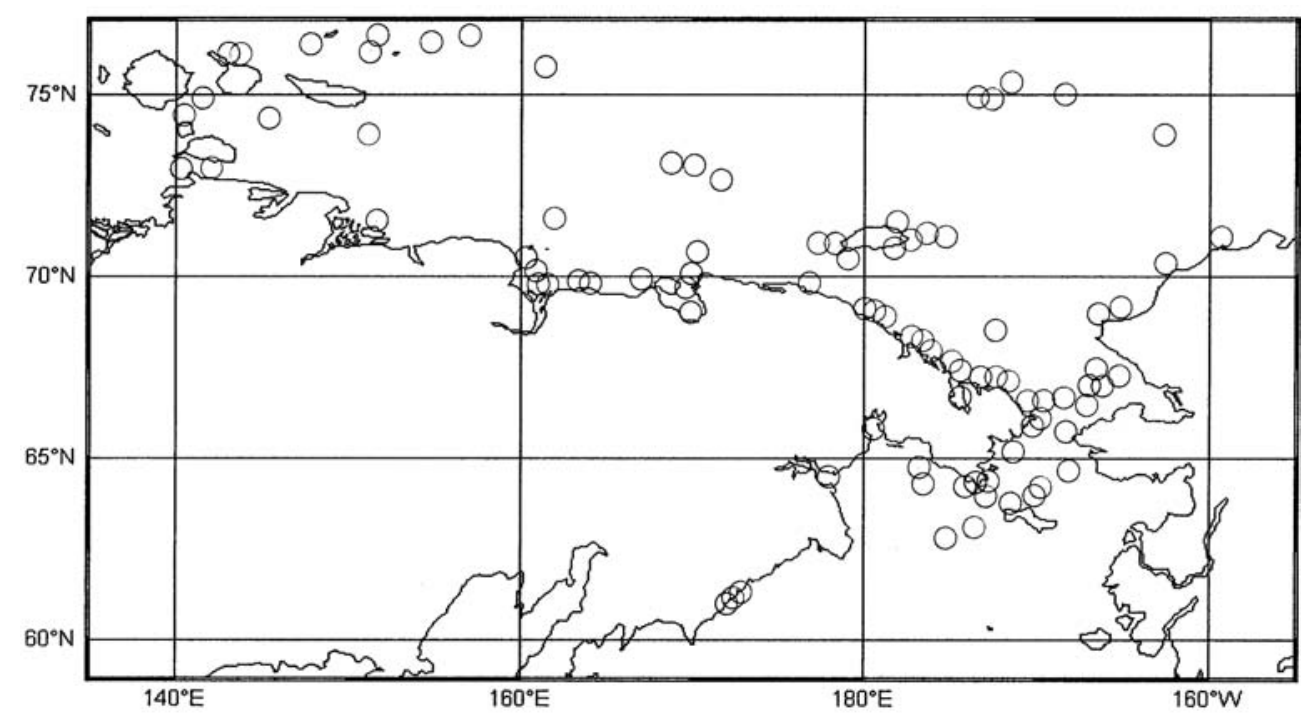

Fig. 6. Stations where boreal-Arctic Malacostraca species were sampled in the Chukchi, Bering, and East Siberian seas. After Petryashov, 2002b, fig. 4.

Рис. 6. Станции, на которых в Чукотском, Беринговом и Восточно-Сибирском морях были пойманы бореально-арктические виды Malacostraca (по: Петряшев, 2002b, рис. 4).

subtropical-boreal species usually spread in the Chukchi Sea with the flows of Pacific water. The number of such species decreases with the spreading and transformation of Pacific water from south to the northeast and northwest. In the zones of circulation at the contact between currents of Pacific and Arctic origin, some boreal and subtropical-boreal species can penetrate 
Table 5. Values of similarity indices of Czekanowski-Sørensen $\left(\mathrm{I}_{\mathrm{cs}}\right)$, Szymkewicz-Simpson $\left(\mathrm{I}_{\mathrm{Szs}}\right)$ and Jaccard ( $\left.\mathrm{I}_{\mathrm{J}}\right)$ for adjacent areas $(\%)$.

Таблица 5. Значения индексов общности Чекановского-Съеренсена $\left(\mathrm{I}_{\mathrm{cs}}\right)$, Шимкевича-Симпсона $\left(\mathrm{I}_{\mathrm{Szs}}\right)$ и Жаккара $\left(\mathrm{I}_{\mathrm{J}}\right)$ для сопредельных районов в процентах.

\begin{tabular}{|c|c|c|c|c|c|c|c|}
\hline & & Malac ostraca & Loricata & Gastropoda & Bivalvia & Echinodermata & $\begin{array}{c}\text { Total } \\
\text { macrobenthos }\end{array}$ \\
\hline \multirow{3}{*}{ D1-D2 } & $\mathrm{I}_{\mathrm{CS}}$ & 44.4 & - & 80.2 & 80.7 & 59.1 & 70.0 \\
\hline & $\mathrm{I}_{\mathrm{SzS}}$ & 78.3 & - & 98.6 & 81.4 & 100 & 89.7 \\
\hline & $\mathrm{I}_{\mathrm{J}}$ & 33.9 & - & 67.0 & 67.6 & 41.9 & 53.8 \\
\hline \multirow{3}{*}{ D1-D3 } & $\mathrm{I}_{\mathrm{CS}}$ & 88.3 & 100 & 97.6 & 90.3 & 98.4 & 82.3 \\
\hline & $\mathrm{I}_{\mathrm{SzS}}$ & 92.5 & 100 & 98.0 & 93.3 & 100 & 82.4 \\
\hline & $\mathrm{I}_{\mathrm{I}}$ & 79.0 & 100 & 95.2 & 82.4 & 96.8 & 70.0 \\
\hline \multirow{3}{*}{ D2-D3 } & $\mathrm{I}_{\mathrm{CS}}$ & 44.7 & - & 79.8 & 81.3 & 60.5 & 70.6 \\
\hline & $\mathrm{I}_{\mathrm{SzS}}$ & 73.9 & - & 98.6 & 84.7 & 100 & 90.3 \\
\hline & $\mathrm{I}_{\mathrm{J}}$ & 28.8 & - & 66.3 & 68.5 & 43.3 & 54.6 \\
\hline \multirow{3}{*}{ D2-D4 } & $\mathrm{I}_{\mathrm{CS}}$ & 74.1 & - & 97.2 & 93.7 & 78.8 & 90.0 \\
\hline & $\mathrm{I}_{\mathrm{SzS}}$ & 87.0 & - & 100 & 100 & 100 & 98.2 \\
\hline & $\mathrm{I}_{\mathrm{I}}$ & 58.8 & - & 94.6 & 88.1 & 65.0 & 81.8 \\
\hline \multirow{3}{*}{ D3-D4 } & $\mathrm{I}_{\mathrm{CS}}$ & 57.1 & 60.0 & 82.5 & 82.4 & 80.0 & 77.0 \\
\hline & $\frac{\mathrm{I}_{\mathrm{SZS}}}{\mathrm{I}_{\mathrm{S}}}$ & 77.4 & 100 & 98.6 & 84.4 & 100 & 89.2 \\
\hline & $\mathrm{I}_{\mathrm{J}}$ & 40.0 & 42.9 & 70.2 & 70.1 & 66.7 & 62.5 \\
\hline \multirow{3}{*}{ D3-D5 } & $\mathrm{I}_{\mathrm{CS}}$ & 89.7 & 83.3 & 96.5 & 84.1 & 96.7 & 91.5 \\
\hline & $\mathrm{I}_{\mathrm{SzS}}$ & 90.6 & 100 & 99.0 & 90.6 & 96.7 & 92.2 \\
\hline & $\mathrm{I}_{\mathrm{J}}$ & 81.4 & 71.4 & 93.4 & 72.5 & 93.5 & 84.3 \\
\hline \multirow{3}{*}{ D4-D5 } & $\mathrm{I}_{\mathrm{CS}}$ & 63.5 & 75.0 & 81.4 & 93.6 & 80.0 & 81.6 \\
\hline & $\mathrm{I}_{\mathrm{SzS}}$ & 87.1 & 100 & 94.6 & 98.5 & 100 & 95.4 \\
\hline & $\mathrm{I}_{\mathrm{I}}$ & 46.6 & 60.0 & 68.6 & 88.0 & 66.7 & 68.9 \\
\hline \multirow{3}{*}{ D5-D6 } & $\mathrm{I}_{\mathrm{CS}}$ & 91.7 & 88.9 & 92.0 & 93.5 & 96.6 & 92.8 \\
\hline & $\mathrm{I}_{\mathrm{SzS}}$ & 92.6 & 100 & 96.6 & 100 & 100 & 96.7 \\
\hline & $\mathrm{I}_{\mathrm{J}}$ & 84.7 & 80.0 & 85.1 & 87.8 & 93.3 & 86.6 \\
\hline \multirow{3}{*}{ D6-D7 } & $\mathrm{I}_{\mathrm{CS}}$ & 50.7 & - & 69.1 & 61.1 & 73.9 & 62.9 \\
\hline & $\mathrm{I}_{\mathrm{SzS}}$ & 95.0 & - & 100 & 96.7 & 94.4 & 97.4 \\
\hline & $\mathrm{I}_{\mathrm{I}}$ & 33.9 & - & 57.4 & 43.9 & 58.6 & 45.9 \\
\hline \multirow{3}{*}{ D6-D8 } & $\mathrm{I}_{\mathrm{CS}}$ & 64.3 & 66.7 & 84.0 & 75.4 & 88.0 & 77.9 \\
\hline & $\mathrm{I}_{\mathrm{SzS}}$ & 93.1 & 100 & 93.2 & 87.8 & 100 & 92.6 \\
\hline & $\mathrm{I}_{\mathrm{J}}$ & 47.4 & 50.0 & 72.3 & 60.6 & 78.6 & 63.8 \\
\hline \multirow{3}{*}{ D6-D9 } & $\mathrm{I}_{\mathrm{CS}}$ & 49.4 & 33.3 & 46.9 & 69.8 & 46.2 & 55.3 \\
\hline & $\mathrm{I}_{\mathrm{SzS}}$ & 76.9 & 50.0 & 100 & 90.2 & 81.2 & 88.2 \\
\hline & $\mathrm{I}_{\mathrm{I}}$ & 32.8 & 20.0 & 33.7 & 53.6 & 30.0 & 38.2 \\
\hline \multirow{3}{*}{ D7-D8 } & $\mathrm{I}_{\mathrm{CS}}$ & 57.1 & - & 61.7 & 63.3 & 75.0 & 62.8 \\
\hline & $\mathrm{I}_{\mathrm{SZS}}$ & 70.0 & - & 78.7 & 83.3 & 83.3 & 79.1 \\
\hline & $\frac{\mathrm{S}_{\mathrm{ZS}}}{\mathrm{I}_{\mathrm{J}}}$ & 40.0 & - & 44.6 & 46.3 & 60.0 & 45.7 \\
\hline \multirow{3}{*}{ D7-D9 } & $\mathrm{I}_{\mathrm{CS}}$ & 39.1 & - & 57.1 & 67.6 & 55.2 & 56.0 \\
\hline & $\mathrm{I}_{\mathrm{SzS}}$ & 45.0 & - & 73.3 & 80.0 & 72.7 & 57.3 \\
\hline & $\mathrm{I}_{\mathrm{J}}$ & 24.3 & - & 40.0 & 51.1 & 38.1 & 38.9 \\
\hline \multirow{3}{*}{ D7-D10 } & $\mathrm{I}_{\mathrm{CS}}$ & 49.0 & - & 81.2 & 73.2 & 81.1 & 72.3 \\
\hline & $\mathrm{I}_{\mathrm{SzS}}$ & 60.0 & - & 87.2 & 86.7 & 83.3 & 81.7 \\
\hline & $\mathrm{I}_{\mathrm{J}}$ & 32.4 & - & 68.3 & 57.8 & 68.2 & 56.6 \\
\hline \multirow{3}{*}{ D7-D11 } & $\mathrm{I}_{\mathrm{CS}}$ & 31.3 & - & 58.8 & 60.0 & 53.8 & 53.4 \\
\hline & $\mathrm{I}_{\mathrm{SzS}}$ & 41.7 & - & 95.2 & 75.0 & 87.5 & 77.0 \\
\hline & $\mathrm{I}_{\mathrm{J}}$ & 18.5 & - & 41.7 & 42.9 & 36.8 & 36.4 \\
\hline
\end{tabular}


Table 5 (contituing) Таблица 5 (продолжение)

\begin{tabular}{|c|c|c|c|c|c|c|c|}
\hline & & Malacostraca & Loricata & Gastropoda & Bivalvia & Echinodermata & $\begin{array}{c}\text { Total } \\
\text { macrobenthos }\end{array}$ \\
\hline \multirow{3}{*}{ D8-D1 1} & $\mathrm{I}_{\mathrm{CS}}$ & 34.1 & - & 36.2 & 40.6 & 40.0 & 37.3 \\
\hline & $\mathrm{I}_{\mathrm{S} Z \mathrm{~S}}$ & 58.3 & - & 81.0 & 70.0 & 75.0 & 72.1 \\
\hline & $\mathrm{I}_{\mathrm{J}}$ & 20.6 & - & 22.1 & 25.5 & 25.0 & 22.9 \\
\hline \multirow{3}{*}{ D9-D10 } & $\mathrm{I}_{\mathrm{CS}}$ & 69.1 & 50.0 & 64.3 & 75.6 & 60.0 & 70.6 \\
\hline & $\mathrm{I}_{\mathrm{S} 2 \mathrm{~S}}$ & 73.1 & 50.0 & 90.0 & 75.6 & 81.8 & 81.8 \\
\hline & $\mathrm{I}_{\mathrm{J}}$ & 52.8 & 33.3 & 47.4 & 70.8 & 42.9 & 54.5 \\
\hline \multirow{3}{*}{ D10-D1 1} & $\mathrm{I}_{\mathrm{CS}}$ & 39.0 & - & 45.3 & 59.0 & 59.3 & 49.5 \\
\hline & $\mathrm{I}_{\mathrm{SZS}}$ & 66.7 & - & 81.0 & 90.0 & 100 & 83.6 \\
\hline & $\mathrm{I}_{\mathrm{J}}$ & 24.2 & - & 29.3 & 41.9 & 29.6 & 32.9 \\
\hline \multirow{3}{*}{ D10-D12 } & $\mathrm{I}_{\mathrm{CS}}$ & 66.7 & - & 69.8 & 72.2 & 68.6 & 69.2 \\
\hline & $\mathrm{I}_{\mathrm{S} Z \mathrm{~S}}$ & 84.2 & - & 71.2 & 83.9 & 75.0 & 77.1 \\
\hline & $\mathrm{I}_{\mathrm{I}}$ & 50.0 & - & 53.5 & 56.5 & 52.2 & 52.9 \\
\hline \multirow{3}{*}{ D11-D12 } & $\mathrm{I}_{\mathrm{CS}}$ & 38.7 & - & 38.4 & 51.0 & 58.3 & 44.7 \\
\hline & $\mathrm{I}_{\mathrm{S} x \mathrm{~S}}$ & 50.0 & - & 66.7 & 65.0 & 87.5 & 65.6 \\
\hline & $\mathrm{I}_{\mathrm{J}}$ & 24.0 & - & 23.7 & 34.2 & 41.2 & 28.8 \\
\hline
\end{tabular}

Remark. D1-D12 correspond to areas used in the biogeographical analysis (see Fig. 1).

into adjacent relatively cold areas of the Chukchi Sea. A few species of these groups penetrate, together with the most transformed Pacific water, into adjacent Arctic areas, as far as Cape Billings and to the area northwestward of Wrangel Island in the East Siberian Sea and along the canyons to the northern Chukchi Sea. However, these Arctic areas are most probably sterile zones of eviction for such species. Contrary to boreal and subtropical-boreal species, few Arctic and similar to them in the Chukchi Sea Atlantic boreal-Arctic species mainly spread within the sea only in areas that are affected by cold water of Arctic origin: De Long Strait, along Chukchi region coast northwest of Cape Serdtse Kamen, on outer shelf of the sea. Along the Alaskan coast, within the Chukchi Sea, these species were recorded only at Point Barrow (in the region of Barrow Canyon). One of these species was only once recorded in the area of the central banks (D7) and Atlantic high-borealArctic gastropods were twice found in the South Chukchi area (D6). Remarkably, within the Chukchi Sea, i.e. to Cape Serdtse Kamen, the eastern part of southern depression, Herald Canyon, Barrow Canyon, and Point Barrow, there were records of water with small positive temperature values in the near-bottom layer at 20
$50 \mathrm{~m}$ in hydrological summer (late July - September), whereas other areas (D9-D11) were characterized by prevailing or only water with negative temperature.

\section{Acknowledgements}

The investigation was supported by the Ministry of Education and Science of the Russian Federation. This work is part of the project "Arctic marine fauna: data accumulated in Russia" (sub-project of the CoML "Arctic Ocean Diversity" program).

\section{References}

Andriashev A.P. 1939. [The fishes of the Bering Sea and neighbouring waters, its origin and zoogeography.] Leningrad: Leningrad State University Publ. 187 p. [in Russian, with English abstract].

Banner A.H. 1948a. A taxonomic study of the Mysidacea and Euphausiacea (Crustacea) of the northeastern Pacific. Part I. Mysidacea, from family Lophogastridae through tribe Erythropini // Transactions of the Royal Canadian Institute. Vol.26. P.345-399.

Banner A.H. 1948b. A taxonomic study of the Mysidacea and Euphausiacea (Crustacea) of the northeastern Pacific. Part II. Mysidacea, from tribe Mysini through subfamily Mysidellinae // Transactions of the Royal Canadian Institute. Vol.27. P.65-125.

Bogdanov I.P. 1994. [Gastropods Oenopotinae of the East Siberian Sea] // Issledovaniya fauny morei [Explora- 


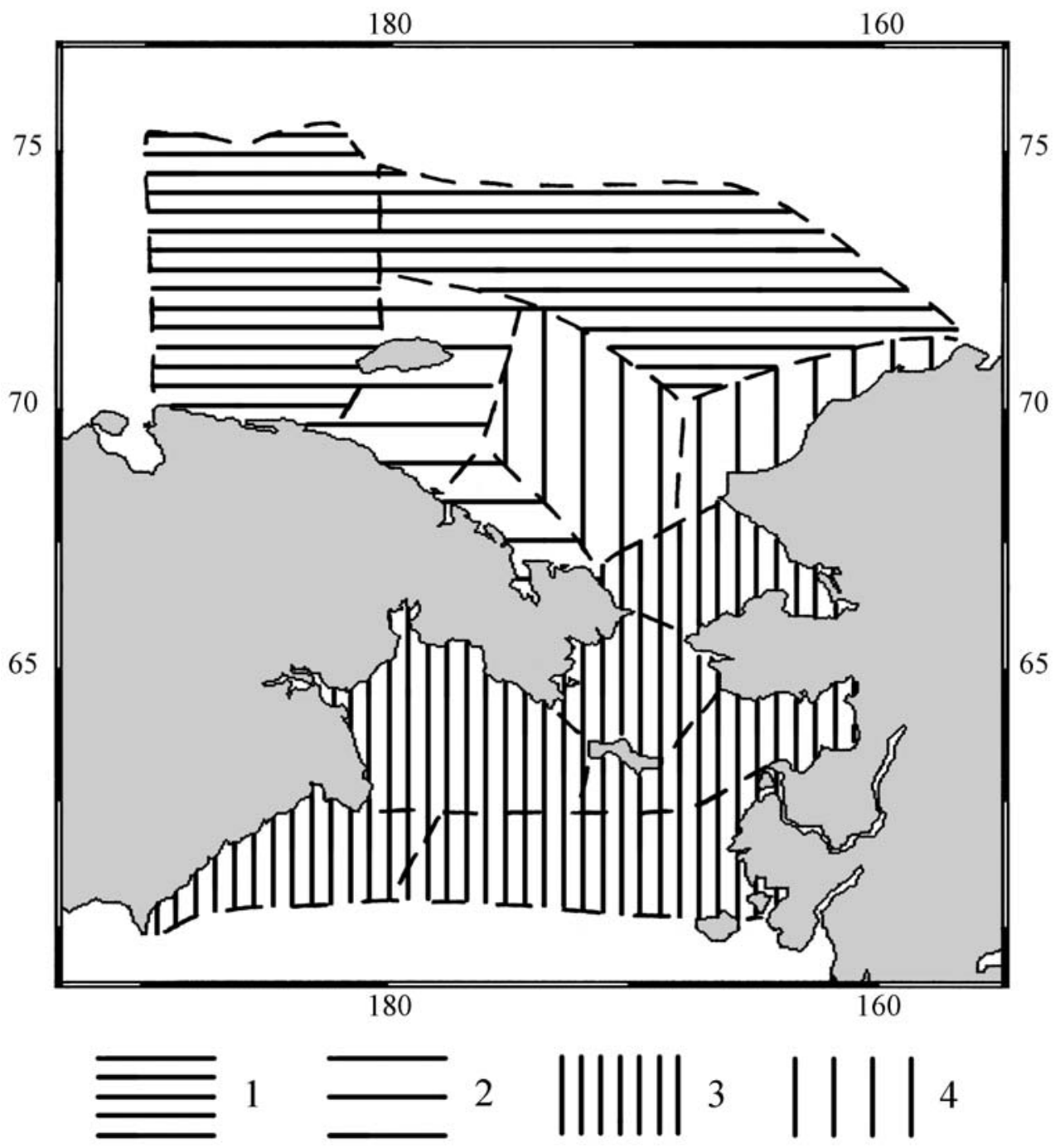

Fig. 7. Division of the Chukchi Sea, the northern part of the Bering Sea and the eastern part of the East Siberian Sea into biogeographical regions; based on comparison the faunas of shelf areas.

1 - Arctic (or Arctic-Atlantic) region, 2 - Arctic part of transition zone, 3 - Northern Pacific boreal region, 4 Northern Pacific part of transition zone.

Рис. 7. Биогеографическое районирование Чукотского моря, северной части Берингова моря и восточной части Восточно-Сибирского моря по фауне макробентоса шельфа.

1 - Арктическая (или Арктатлантическая) биогеографическая область, 2 - Арктическая часть переходной зоны, 3 - Северотихоокеанская бореальная биогеографическая область, 4 - Северотихоокеанская часть переходной зоны.

tions of the fauna of the seas]. Vol.49(57). P.123-130 [in Russian, with English abstract].

Briggs J.C. 1995. Global Biogeography // Development in Paleontology and Stratigraphy. Vol.14. Elsevier. $452 \mathrm{pp}$.

Dall W.H. 1909. Report on a collection of shells from Peru, with a summary of the littoral marine Mollusca of the
Peruvian Zoological province // Proceedings of the United States National Museum. Vol.37. P.147-294. Djakonov A.M. 1950. [Asteroidea of the Seas of the USSR] // Opredeliteli po faune SSSR [Keys to the fauna of the USSR, published by the Zoological Institute of the Academy of Sciences of the USSR]. Vol.34. P.1-212 [in Russian]. 
Djakonov A.M. 1952. [Echinodermata of the Chukchi Sea and Bering Strait] // Krainyi severo-vostok Soyuza SSR [Extreme North-East of the USSR.] Vol.2.P.286310 [in Russian].

Djakonov A.M. 1954. [Ophiuroidea of the Seas of the USSR] // Opredeliteli po faune SSSR [Keys to the fauna of the USSR, published by the Zoological Institute of the Academy of Sciences of the USSR]. Vol.55. P.1-136 [in Russian with English translation: 1967. Jerusalem. 123 p].

Feder H.M., Jewett S.C. 1978. Survey of the invertebrates of Morton Sound, southeastern Chukchi Sea, and Kotzebue Sound. Alaska: IMS Report R78-1, Fairbanks. 124 p.

Filatova Z.A. 1957. [Zoogeographical division of northern seas by distribution of Bivalvia] // Trudy Instituta Okeanologii [Transactions of the Institute of Oceanology]. Vol.23. P.195-215 [in Russian with English abstract].

Fischer P. 1887. Manuel de conchyliologie et de Paléontologie conchyliologique. Paris. 1369 p.

Foster N.R. 1981. A synopsis of the marine prosobranch gastropod and bivalve mollusks in Alaskan waters. Alaska: IMS R81-3, Fairbanks. 479 p.

Golikov A.N. 1980. [Mollusca, Buccinae of the World ocean]. Fauna SSSR [Fauna of USSR, published by the Zoological Institute of the Academy of Sciences of the USSR.] Vol.5. No.2. P.1-465 [in Russian with English abstract].

Golikov A.N. 1994. [Shell-bearing gastropods of the East Siberian Sea] // Issledovaniya fauny morei [Explorations of the fauna of the seas.] Vol.49 (57). P.67-122 [in Russian with English abstract].

Golikov A.N., Gagaev S.Y., Galtsova V.V., Golikov A.A., Dunton K., Menshutkina T.V., Novikov O.K., Petryashov V.V., Potin V.V., Sirenko B.I., Schonberg S., Vladimirov M.V. 1994. [Ecosystems of Chaun Bay of the East Siberian Sea] // Issledovaniya fauny morei [Explorations of the fauna of the seas.] Vol.47 (55). P.4-111 [in Russian with English abstract].

Gorbunov G.P. 1952. [Bivalvia of the Chukchi Sea and Bering Strait] // Krainyi severo-vostok Soyuza SSR [Extreme North-East of the USSR.] Vol.2. P.216-278 [In Russian].

Gurjanova E.F. 1952. [Crustacea - Malacostraca of the Chukchi Sea and Bering Strait] // Krainyi severovostok Soyuza SSR [Extreme North-East of the USSR.] Vol.2. P.169-215 [in Russian].

Holmquist C. 1973. Taxonomy, distribution and ecology of the three species: Neomysis intermedia (Czerniavsky), N. awatschensis (Brandt) and N. mercedis Holmes (Crustacea, Mysidacea) // Zoologische Jahrbücher. Abteilung für Systematik, Ökologie und Geographie der Tiere. Bd.100. S.197-222.

Holmquist C. 1975. A revision of the species Archaeomysis grebnitzkii Czerniavsky and A. maculata (Holmes) (Crustacea, Mysidacea) // Zoologische Jahrbücher. Abteilung für Systematik, Ökologie und Geographie der Tiere. Bd.102. S.51-71.

Holmquist C. 1980. Xenacanthomysis - a new genus for the species known as Acanthomysis pseudomacropsis
(W.M.Tattersall, 1933) (Crustacea, Mysidacea) // Zoologische Jahrbücher. Abteilung für Systematik, Ökologie und Geographie der Tiere. Bd.107. S.501-510.

Holmquist C. 1981a. Exacanthomysis gen. nov., another detachment from the genus Acanthomysis (Crustacea, Mysidacea) // Zoologische Jahrbücher. Abteilung für Systematik, Ökologie und Geographie der Tiere. Bd.108. S.247- 263.

Holmquist C. 1981b. The genus Acanthomysis Czerniavsky, 1882 (Crustacea Mysidacea) // Zoologische Jahrbücher. Abteilung für Systematik, Ökologie und Geographie der Tiere. Bd.108. S.386-415.

Holmquist C. 1982. Mysidacea (Crustacea) securad during investigations along the west coast of North America by the National Museums of Canada, 1955-1966, and some inferenses drawn from the results // Zoologische Jahrbücher. Abteilung für Systematik, Ökologie und Geographie der Tiere. Bd.109. S.469-510.

Kafanov A.I. 1991. [Bivalve molluscs and faunistic biogeography of the Northern Pacific.] Vladivostok: Far East Branch of Academy of Sciences of the USSR. 196 p. [in Russian with English abstract].

Kussakin O.G. 1967. [Isopoda and Tanaidacea of the coastal zone of the Antarctic and Subantarctic] // Issledovaniya fauny morei [Explorations of the fauna of the seas]. Vol.4. No.12. P.220-380 [in Russian].

Kussakin O.G. 1979. [Marine and brackish-water Isopoda of the cold and temperate waters of the Northern Hemisphere. I. Suborder Flabellifera] // Opredeliteli po faune SSSR [Keys to the fauna of the USSR, published by the Zoological Institute of the Academy of Sciences of the USSR]. Vol.122. P.1-472 [in Russian].

Kussakin O.G. 1982. [Marine and brackish-water Isopoda of the cold and temperate waters of the Northern Hemisphere. II. Suborder Anthuridea, Microcerberidea, Valvifera and Tyloidea] // Opredeliteli po faune SSSR [Keys to the fauna of the USSR, published by the Zoological Institute of the Academy of Sciences of the USSR.] Vol.131. P.1-462 [in Russian].

Kussakin O.G. 1988. [Marine and brackish-water Isopoda of the cold and temperate waters of the Northern Hemisphere. III. Suborder Asellota. Part 1] // Opredeliteli po faune SSSR [Keys to the fauna of the USSR, published by the Zoological Institute of the Academy of Sciences of the USSR.] Vol.152. P.1-501 [in Russian].

Kussakin O.G. 1999. [Marine and brackish-water Isopoda of the $\mathrm{c}$ old and temperate waters of the Northern Hemisphere. III. Suborder Asellota. Part 2] // Opredeliteli po faune SSSR [Key to the Fauna of the USSR, published by the Zoological Institute of the Russian Academy of Sciences.] Vol.169. P.1-384 [in Russian].

Kussakin O.G. 2003. [Marine and brackish-water Isopoda of the cold and temperate waters of the Northern Hemisphere. III. Suborder Asellota. Part 3] // Opredeliteli po faune SSSR [Keys to the fauna of the USSR, published by the Zoological Institute of the Academy of Sciences of the USSR.] Vol.171. P.1-381 [in Russian]. 
Makarov V.V. 1938. [Crustacea. Anomura] // Fauna of SSSR [Fauna of USSR, published by the Zoological Institute of the Academy of Sciences of the USSR.] Vol.10. No.3. P.1-325 [in Russian, with English abstract].

Makarov V.V. 1941. [The decapod Crustacea of the Bering and Chukchi Seas] // Issledovaniya dalnevostochnykh morei [Explorations of the Far Eastern seas]. Vol.1. P.111-163 [in Russian, with English abstract].

McLaughlin P.A. 1974. The hermit crabs (Crustacea, Decapoda, Paguridea) of northwestern North America // Zoologische Verhandelingen. Vol.130. P.1-396.

Naumov A.D., Fedjakov V.V. 1994. [Clams of the East Siberian Sea] // Issledovaniya fauny morei [Explorations of the fauna of the seas.] Vol.49(57). P.44-66 [in Russian, with English abstract].

Nikiforov E.G., Shpaikher A.O. 1980. [Patterns of largescale fluctuations of the hydrological regime in the Arctic Ocean.] Leningrad: Hydrometeoizdat. 269 p. [in Russian].

Pesenko Yu.A. 1982. [Principles and methods of quantitative analysis in faunal studies.] Moscow: Nauka. 287 p. [in Russian].

Petryashov V.V. 2002a. [Leptostraca, Mysidacea, Isopoda and Decapoda (Anomura) (Crustacea, Malacostraca) of the Chukchi Sea and adjacent waters: habitat conditions and species composition]//Biologiya morya [Russian Journal of Marine biology.] Vol.28. No.2. P.85-92 [in Russian, with English abstract].

Petryashov V.V. 2002b. [Leptostraca, Mysidacea, Isopoda and Decapoda (Anomura) (Crustacea, Malacostraca) of the Chukchi Sea and adjacent waters: biogeography and history of fauna formation] // Biologiya morya [Russian Journal of Marine biology.] Vol.28. No.3. P.161-169 [in Russian, with English abstract].

Petryashov V.V. 2005. [Biogeographical division of the North Pacific sublittoral and upper bathyal zones by the fauna of Mysidacea and Anomura (Crustacea)] // Biologiya morya [Russian Journal of Marine biology.] Vol.31. No.4. P.233-250 [in Russian, with English abstract].

Petryashov V.V. 2009. [Biogeographical division of the Arctic and North Atlantic based on the fauna of mysids (Crustacea: Mysidacea)] // Biologiya morya [Russian Journal of Marine biology]. Vol.35. No.2. P.87-106 [in Russian, with English abstract].

Petryashov V.V., Golikov A.A., Schmid M., Rachor E. 2004. [Macrobenthos of the Laptev Sea shelf] // Issledovaniya fauny morei [Explorations of the fauna of the seas.] Vol.54(62). P.9-27 [in Russian, with English abstract].

Rathbun M.J. 1910. Decapod Crustaceans of the Northwest coast of North America // Alaska. Vol.5. No.10. P.3-210.
Ratmanov G.E. 1937. [Contributions to the study of the hydrology of the Bering and Chukchee Seas] // Issledovaniya dalnevostochnykh morei [Explorations of the Far Eastern seas.] Vol.5. P.10-118 [in Russian, with English abstract].

Scarlato O.A. 1981. [Bivalvia of the temperate waters of North-west Pacific] // Opredeliteli po faune SSSR [Keys to the fauna of the USSR, published by the Zoological Institute of the Academy of Sciences of the USSR.] Vol.126. P.1-480 [in Russian].

Scarlato O.A., Golikov A.N. 1985. [Biology. Arctic Ocean] // A.F. Treshnikov, S.S. Sal'nikov (eds.). Geographiya Mirovogo okeana. Severnyi Ledovityi i Yuzhnyi okeani [Geography of the World Ocean. Arctic and Southern Oceans] Leningrad: Nauka. P.102-119 [in Russian]. Sirenko B.I. 2010a. [Chapter VI. Chitons (Molluska, Polyplacophora) of the Chukchi Sea and Bering Strait] // Issledovaniya fauny morei [Explorations of the fauna of the seas.] Vol.64 (72). P.98-153 [in Russian, with English abstract).

Sirenko B.I. 2010b. [Chapter VII. The prosobranchs of the gastropodas (Molluska, Gastropoda, Prosobranchia) of the Chukchi Sea and Bering Strait, their species composition and distribution] // Issledovaniya fauny morei [Explorations of the fauna of the seas]. Vol.64 (72). P.104-103 [in Russian, with English abstract].

Sirenko B.I., Vassilenko S.V., Petryashov V.V. 2008. [Appendix 2. Types of distribution ranges of species inhabiting the Arctic Ocean] // Issledovaniya fauny morei [Explorations of the fauna of the seas.] Vol.61(69). P.221-231 [in Russian].

Smirnov A.V., Smirnov I.S. 1994. [Echinoderms of the East Siberian Sea] // Issledovaniya fauny morei [Explorations of the fauna of the seas.] Vol.49(57). P.131182 [in Russian, with English abstract].

Smirnov A.V., Smirnov I.S. 2009. [Chapter VIII. Echinoderms of the Chukchi Sea and Bering Strait] // Issledovaniya fauny morei [Explorations of the fauna of the seas.] Vol.64(72). P.154-199 [in Russian, with English abstract].

Tattersall W.M. 1951. A review of the Mysidacea of the United States National Museum // Bulletin of the United States National Museum. Vol.201. P.1-292.

Tzvetkova N.L. 1975. [Coastal gammarids of the Northem and Far Eastern seas of the USSR and adjacent waters.] Leningrad: Nauka. 258 p. [in Russian].

Ushakov P.V. 1952. [Chukchi Sea and its bottom fauna] // Krainyi severo-vostok Soyuza SSR [Extreme NorthEast of the USSR.] Vol. 2. P.5-82 [in Russian].

Vassilenko S.V. 1994. [The Cumacea fauna of the Chaun Bay of the East Siberian Sea. Issledovaniy fauny morei [Explorations of the fauna of the seas.] Vol.47(55). P.195-210 [in Russian, with English abstract].

Woodward S.P.A. 1856. A manual of the Mollusca; or a rudimentary treatise of recent and fossil shells. London. 486 p. 